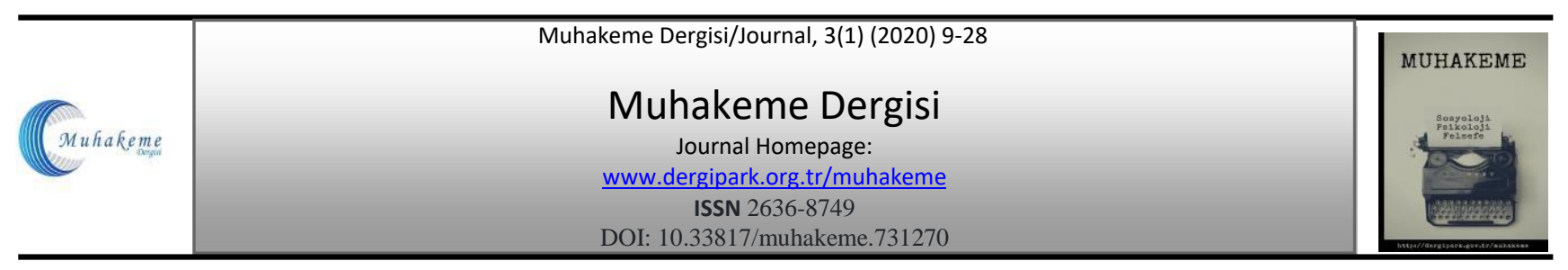

\title{
Duygusal Zekâ ve Liderlik
}

\section{Pelin Vardarlıer ${ }^{1}$ Hatice Kübra Yapıcı ${ }^{2}$}

\section{ÖZET}

Son yıllarda yapılan araştırmalar, mantıksal zekânın özel ve iş yaşamındaki başarıya katkısının çok fazla olmadığını göstermektedir. Bu doğrultuda duygusal zekâ kavramı ön plana çıkmaktadır. Duygusal zekâ, mantığın etkisinin azalmasına değil, insan duygularının vazgeçilmezliğine dayanmaktadır. Bir anlamda bu kavram toplumsal alanda duygu ile düşünceyi barıştırmaya yönelik bir hareketin sonucudur. İşletmeler, büyüme ve gelişmesini engelleyen durumlarına yönelik çözüm bulma konusunda zorluk yaşamaktadır. Bu zorluklara uygun çözümler getirme noktasında sorumluluk öncelikle liderlere verilmiştir. Yüksek duygusal zekâya sahip liderler, kendilerinin ve çalışanlarının duygularını yönetebilen, motive edebilen, etkin ilişkiler kurabilen, onların iş tatminlerini ve performanslarını artırabilen kişilerdir. Bu çalışmada da, duygusal zekâ kavramı ve önemi anlatılmaya çalışılmış ayrıca, yüksek duygusal zekâya sahip liderlerin kurumsal başarıya etkisi üzerinde durulmuştur.

Anahtar Kelimeler: Duygusal zekâ, liderlik, liderlerde duygusal zekâ

\section{Emotional Intelligence And Leadership}

\begin{abstract}
Researches made in recent years show that logical intelligence does not contribute much to the success of private and business life. Accordingly, the concept of emotional intelligence comes to the fore. Emotional intelligence is based on the indispensability of human emotions, not on the reduction of the influence of logic. In a sense, it is the result of a movement to reconcile emotion and thought in the social sphere. Businesses have difficulties in finding solutions for situations that prevent growth and development. At the point of bringing appropriate solutions to these challenges, it has given the responsibility primarily to the leaders. Leaders with high emotional intelligence are those who can manage, motivate, build effective relationships, and improve their job satisfaction and performance. In this study, the concept and importance of emotional intelligence is tried to be explained, and the effect of leaders with high emotional intelligence on corporate success is emphasized.
\end{abstract}

Keywords: Emotional intelligence, leadership, emotional intelligence in leaders.

\section{Gíriș}

Duygusal zekâ kavramının, bireyin çalışma ve özel hayatındaki olumlu etkisi, otuz yıl önce yapılan çalışmalar sayesinde anlaşılmıştır. Duygusal zekâ kavramının dünya üzerinde bilinirliğinin artması ile birlikte, insanlar sadece tek bir zekâ türüne sahip olmadığını, genel zekâ içerisinde farklı zekâ türlerine

\footnotetext{
${ }^{1}$ Doç.Dr., İstanbul Medipol Üniversitesi, İnsan Kaynakları Yönetimi, pvardarlier@medipol.edu.tr

${ }^{2}$ Yüksek Lisans Öğrenci, İstanbul Medipol Üniversitesi, haticekubrayapici@gmail.com.
} 
de sahip olduklarını fark etmiştir. Bu doğrultuda, duygusal zekâ bireyin kendi duygularının farkına varmasına, duygularını anlamasına, kontrol etmesine ve empati kurabilmesine yardımcı olmaktadır. En basit tanımıyla bireyin kendi duyguları ile yüzleşmesi olarak ifade edilmektedir. Duygusal zekâ ile birey, diğer bireylerin duygularını sezip, onların duygularını anlayabilmektedir. Bu nedenle diğer bireyler ile uzun vadeli olumlu sürdürebilir bir iletişim kurabilmektedir. Duygusal zekâ bireyin hem kendisini hem de diğer bireylerin davranışlarını kontrol edebilmesini sağlar. Böylelikle duygusal zekânın adeta bireyin duygularından oluşan bir kütüphanesi olduğunu söylemek mümkündür. Duygularını kontrol edemeyen kişiler ise, iletişim çatışmaları içerisinde yeteneklerini engelleyen bir içsel mücadeleye girmektedir. Nitekim bu noktada liderlerin bu kişilere duygularını yönetme konusunda destek olmaları beklenmektedir. Duyguları başarıyla yönetme, kişilere zihinsel ve fiziksel huzur açısından yarar sağlamaktadır. Hem kendimizin hem de başkalarının duygularını düzenleme yeteneği etkili liderlik ile mümkündür.

Duygusal zekâ hem özel hayatımızda hem de iş hayatında insanlara rehberlik görevi görmektedir. Duygusal zekâ genel olarak bireyin kendi duygularının farkına varmasına, duygularını tanımlamasına, duyguları arasında farklılıkları görebilmesine, çevresindeki diğer bireylerin duygularını anlayabilmesine, kendisini başkasının yerine koyabilmesine yardımcı olmaktadır. Duygusal zekâ sadece kişisel hayattaki amaçlar dışında iş dünyasında hem kişisel hem de bireysel amaçlarını gerçekleştirmesine katkıda bulunana bir kavramdır. İşletmelerin başarılı ve etkili sonuçlar elde etmesini sağlayan kilit faktör liderliktir. Liderlik, bireyleri etkileyerek, onların motivasyonunu yükselterek, ulaşılması istenen hedeflere başarılı bir şekilde gerçekleşmesini sağlamaktadır.

Bu çerçevede amacı duygusal zekâ kavramını liderlik açısından irdelemek olan bu çalışmada, duygusal zekâ ve liderlik ilişkisi üzerine bir derleme yapılması amaçlanmıştır. Bu bağlamda öncelikle duygusal zekânın ne olduğu, duygusal zekâ modelleri farklı perspektiflerden değerlendirilmiştir. Ardından liderlik kavramı ve özellikleri kısaca incelenmiş olup liderlikte duygusal zekânın değerine yer verilmiştir. Son olarak yüksek duygusal zekâya sahip liderlerin özellikleri ve işletmeler açısından önemi kısaca özetlenmiştir.

\section{Duygusal Zekâ Tanımı}

Duygusal zekâ; duyguyu doğru algılama, değerlendirme ve ifade etme yeteneğidir. Duygulara erişebilme veya duygu üretebilme becerisidir. Duygusal bilgiyi anlayabilmektir (Suciu vd., 2014:550). Bir başka deyişle, duygusal zekâ; duygularını gereken zamanda oluşturabilme, sürdürebilme, kontrolünü sağlayabilme ve diğer bireyler ile etkili duygusal ilişki kurabilme becerisidir (Doğan \& Demiral, 2007:212). Duygusal zekâ, bir kişinin çevresel talepler ve baskılarla başa çıkma yeteneğini etkileyen bir dizi tanınmayan beceri, yetenek ve yeterlilik olarak tanımlanabilir (Johnson \& Indvik, 1999:85). Bir başka tanım olarak ise duygusal zekâ, bireyin kendini olumlu yönde geliştirmesini ve ilerlemesini sağlayan, yetenekleri ile diğer bireylerle olan iletişimine düzen vermesidir (Taşkıran \& Köse, 2016:581). Duygusal zekâ kavramını basit bir şekilde tanımlamak istersek, duyguların akla uygun, doğru ve yerinde kullanılmasıdır (Çakar \& Arbak, 2004:34).

Duygusal zekâ ile bireyin duygularını sezmesi, duygularını anlaması, duygularını açıklaması, duygularını kontrolünü sağlayabilmesini, negatif duygularının üstesinden gelebilmesini, bireyin üretken olmasını, yenilikçi olabilmesini, performansını yükseltmesi için kendini güdülemesini, çevresindeki bireylerin duygularını sezmesini, diğer bireyler ile sağlıklı iletişimlerini yürütebilmesini sağlar (Somuncuoğlu, 2005:272). Aynı zamanda duygusal zekâ bireylerin isteklerini daha sonra gerçekleştirmek üzere erteleyebilmesini, çevresindeki bireylere karşı anlayışlı olabilmesini, derin ve içten duygularını hissedebilmesini, sağlıklı iletişim kurup, başarılı bir şekilde yürütmesini sağlayan, öğrenebilir kabiliyettir (Acar, 2002: 56). Araştırmacıların duygusal zekâ kavramı üzerine yürüttügü çalışmalara göre bu kavram hakkında çeşitli tanımlamalar yapılmıştır.

Daniel Goleman'a göre, duygusal zekâ; bireyin eyleme geçmesini sağlayan, önüne çıkan aksiliklerin üstesinden gelebilmesini, duygu durumlarını kontrol edebilmesini, empati kurabilmesini kolaylaştıran özelliktir (Goleman, 2011). Bar-on'a göre duygusal zekâ, bireylerin kendisini anlatabilmesini, diğer bireyleri anlayabilmesi, hayatında ortaya çıkan problemlerin üstesinden gelebilmesini sağlayan, duygusal, bireysel ve sosyal anlamda kabiliyet ve yeterliliğe sahip olmasıdır (Bar-On, 2006: 3). Cooper ve Sawaf'a göre, bireyler arası bağı ve bu bağın etkisinin sağlandığı kaynak olarak duyguları sezmek, duyguları kavraması ile etkili ve başarılı bir şekilde yön verebilme yeteneğidir (Cooper \& Sawaf, 
1998:13). Poskey'e göre ise, duygusal zekâ kavramı, bireyin davranışlarını, ruh hallerini ve dürtülerini tanıma ve duruma veya ortama göre duygularını en iyi şekilde yönetme yeteneğini gösteren bir dizi yeterliliktir. Kişinin duygularına dikkat etmesi ve farklılıklarını görebilmesi, birey kendisini ve başkalarının duygularını doğru tanınması, duygular üzerinde kontrol sahibi olmasını, farklı koşullarda uygun duygu ve davranışlarla yanıt verebilmesidir (Poskey, 2006:1). Kunnanatt'a göre duygusal zekâ, Bireyin duygularını sosyal ortamında kişilerarası etkililik için bir rehber olarak kullanma yeteneğidir. Duygusal zekâ ile bireyler sosyal çevrede diğer bireyler ile etkileşime girerken, etkili bir iletişim sağlanması için sosyal ilişkilerin ve duygusal destek yapılar ağının sahibi olurlar (Kunnanatt, 2004: 489). Martinez'a ise duygusal zekâ kavramını, bir kişinin çevresel talepler ve baskılarla başa çıkma yeteneğini etkileyen bir dizi tanınmayan beceri, yetenek ve yeterlilik olarak tanımlamıştır (MartinezPons, 1997:5).

Duygusal zekâ ile ilgili yapılan tanımlamalardan yola çıkarak duygusal zekânın bireyin kendisini anlayabilmesi, denetimini sağlayabilmesini, motivasyonunu yükseltmesini, önüne çıkan engellerin üstesinden gelebilmesini sağlayan bir yetenek olduğunu söylemek mümkündür. Başka bir deyişle duygusal zekâ, bireyin duygusal dalgalanmalarını denetim altında tutmasını, duygularını ve yeteneklerinin anlaşılmasını sağlayan, farklı yetenekler için değişimin desteklenmesi olarak tanımlanmaktadır. Aynı zamanda kişisel ve çalışma alanındaki amaçlarına doğru odaklanmış, başkalarının duygularını, duygusal ihtiyaçlarını ve sorunlarını algılamayabilmesi sağlayan yetenektir (Mabaçoğlu, 2006:44). Salovey ve Mayer' a göre duygusal zekâ ise, bireyin hem kendisi hem de diğer bireylerin duygularını analiz etmeye yardımcı olmaktadır. Bireyin duygularını denetim altında tutmasını sağlar. Buna ek olarak bireyin hayatındaki başarıyı, içindeki motivasyonunu açığa çıkaran, duygulardan yararlanma firsatını sağlayan becerilerin birleşimi olarak tanımlanmıştır (Salovey \& Mayer, 1990:185).

Geçmişten günümüze kadar hayatımızda duygusal zekâ kavramı ile ilgili farklı terimler üzerinden yapılan tanımlamalar yer almaktadır. Duygusal zekânın farklı kavramlar altında bilimsel literatürde uzun süredir var olduğunu ve yaşamın kilit noktası olarak tanımlandığı yıllar içerisinde yapılan araştırmaların sonuçlarından hareketle gözlemlenmektedir.

\section{Duygusal Zekâ Gelişim Süreci}

Duygusal zekâ araştırmaları yirminci yüzyılda Thorndike'nin 1920'de sosyal zekâyı, 1970 ve 1990 tarihleri arasında duygusal zekâyı açıklamaya yönelik araştırmaların başlandığı dönemi kapsamaktadır. $\mathrm{Bu}$ çalışmaların çoğu, sosyal olarak yetkin davranışları tanımlamaya ve değerlendirmeye odaklanmıştır (Thorndike,1920: 228). Thorndike tarafından çalışmasında tanımlanan sosyal zekâyı cinsiyet ve yaş fark etmeksizin, tüm bireyleri anlama becerisi ve birey ilişkilerinde geniş sezgilere sahip olmak olarak açıklanmıştır (Thorndike,1920: 228). Thorndike'nin yürüttüğü bu çalışma duygusal zekâ kavramının üzerine yapılan araştırmalar için zemin hazırlamıştır. Thorndike'nin sosyal zekâ çalışmasının sonuçlarını ise David Wechsler araştırmasının bulguları ile desteklemiştir. Bilişsel zekâ testlerini tasarlayan David Wechsler, 1940 yılında duygusal zekâ kavramını desteklemek amaciyla yürüttüğü çalışmada duygusal etkenler bulmuştur (Eröz, 2013:215). Araştırma sonuçlarında, bilişsel zekâ (IQ) testlerinde insanların zekâsında analitik dışı zekâ bölümlerinde değerlendirebileceğini belirtilmiştir (Yıldırım, 2012:22). 1920 ve 1940 arası yapılan çalışmalarda duygusal nitelikleri taşıyan bir zekâ türünün keşfedildiği anlaşılmaktadır. 1970 yılına kadar duygusal zekâ üzerine yapılan çalışmalarda duygu ve zekâ kavramlarını ayırarak, bu iki kavram için farklı çalışmalar yapılmıştır. 1970 sonrasına bakıldığında ise, 1990 yıllarına kadarda duygu ve zekâ kavramını birlikte ele alan bir çalışma yapılmamıştır. 1970 ve 1989 yılında sadece duyguların tanımı, fikirler üzerindeki etkisi yönelik bir araştırma gerçekleştirilmiştir. Özetlemek gerekirse, 1970 ve 1990 tarihleri duygusal zekâyı açıklamaya yönelik araştırmaların başlandığı dönemi kapsamaktadır (Altıntaş, 2009:19). 1970 ve 1990 yılları arasında yapılan araştırmaların içinde çoklu zekâ teorisine yönelik araştırmaların da yapıldığı görülmektedir.

\section{Duygusal Zekâ İle İlgili Geliştirilen Modeller}

Duygusal zekâ kavramının ortaya çıkmasından bu yana araştırmacılar tarafından birçok model öne sürülmüştür. Oluşturulan bu modeller duygusal zekânın yetenek, beceri ve boyutlarını kapsamaktadır. 
Geliştirilen duygusal zekâ modelleri ikiye ayrılmaktadır. Bar-On, Cooper ve Sawaf, Daniel Goleman'ın geliştirdikleri modeller karma model olarak adlandırılmaktadır. Slovey ve Mayer geliştirdikleri model ise yetenek modeli olarak belirtilmiştir (Yıldırım, 2012:22).

\section{Salovey ve Mayer Duygusal Zekâ Modeli}

Salovey ve Mayer duygusal zekâyı bireyin kendi duygularını ve diğer bireylerin duygularını izleyebilme ve inceleyebilme, gözlemlediği duyguları arasındaki farklılıklarını ayırt edebilme, elde edilen veriler ile bireyin fikir yürütmesine ve hareketlerini yön vermesi için yaralanması olarak ifade etmiştir (Salovey \& Grewal, 2005:281). Duygusal zekâyı kişilik özelliklerden ayrı tutarak, duygusal zekâyı yetenek veya yetkinlik temelli olarak belirtmiştir. Duygusal zekâ kavramını bir yetenek olarak adlandırmaktadır. Duygusal zekâ, bireyin duyguları hakkında akıl yürütebilmesini ve bilişsel süreçleri geliştirmesi için duygusal bilgileri işleme kapasitesini ifade ettiğini belirtmektedir (Brackett \& Salovey, 2006:35).

Salovey ve Mayer duygusal zekâ üzerinde yürüttüğü çalışmaları geliştirerek bir model tasarlamıştır. İlk olarak, duygusal zekâ modelinde bulunan boyutları analiz edebilmek için ilk olarak MEIS modelini oluşturmuştur. Fakat geleneksel kişiye özgü nitelikler ile çelişkilerin oluşması ve MEIS' in güvenirliğinde sorunlar oluştuğu gözlemlenmiştir. Caruso, Mayer ve Salovey bir araya gelerek duygusal zekâ için bir ve iki versiyon olarak MSCEIT modelini tasarlamıştır (Çakar \& Arbak, 2004:36). Salovey ve Mayer duygusal zekâ modelini dört boyuta ayırmıştır. Bu dört boyut ise, duyguları doğru bir şekilde algılamak, düşünmeyi kolaylaştırmak için duyguları kullanmak, duyguları, duygusal dili ve duyguların ilettiği sinyalleri saptamak ve duyguları yönetebilmedir (Mayer, Salovey, \& Caruso, 2008: 507).

Duygusal zekâ modelinin birinci dalında duyguları doğru bir şekilde algılamak yer almaktadır. Duyguları doğru algılamak duyguları doğru bir şekilde algılama kapasitesini içerir. Duygusal algı, yüz ifadelerindeki duygusal sinyallere, ses tonuna ve yüz ifadelere dikkat etmeyi ve doğru bir şekilde duygusal kodları çözmeyi içerir (Mayer \& Salovey, 2007:7). Duygusal zekâ modelinin ikinci dalında, düşünceyi kolaylaştırmak için duygu kullanımı yer almaktadır. Düşünceyi kolaylaştırmak için duygu kullanımı, dikkatlice odaklama ve daha rasyonel, mantıklı, yenilikçi ve yaratıcı düşünmek için duyguları kullanma becerisiyle ilgilidir. Duyguları kullanmak, akıl yürütme, problem çözme, karar verme ve kişilerarası iletişim gibi belirli bilişsel girişimlere yardımcı olan bir beceridir (Brackett \& Salovey, 35:2006). Duygusal zekâ modelinin üçüncü dalında duyguları, duygusal dili ve duyguların ilettiği sinyalleri saptamak yer almaktadır. Modelin üçüncü dalı, karmaşık duyguları ve duygusal zincirleri anlama, duyguların bir aşamadan diğerine nasıl geçtiğini anlama yeteneği ile ilgilidir. Kısaca, duyguları tanıma, nasıl ortaya çıktıklarını bilme ve buna göre akıl yürütme yeteneğidir (Mayer, 2002:7). Duygusal zekâ modelinin dördüncü dalı ise, duyguları yönetebilmektir. Bu kısım, bireyin kendini ve diğer bireylerin duygu durumlarını düzenleme veya düzen verme yeteneği ile ilgilidir. Birey kendi duygularını yönetirken aynı zamanda diğer bireylerinde duygularını doğru bir şekilde izleyebilmelidir. Ayrıca bireylerin duygularını ayırt edebilmeleri, duygularını değiştirecek stratejiler kullanabilmeleri ve bu stratejilerin etkinliğini değerlendirebilmeleri gerekmektedir (Brackett \& Salovey, 2006:35).

\section{Bar-On Duygusal Zekâ Modeli}

Reuven Bar-On (1997:14) duygusal zekây1; çevresel istekler karşılayabilme ve baskıların üstesinden gelebilme becerisini olarak açıklamıştır. Reuven Bar-On göre, bireyin duygusal zekâ ile duygularında oluşan bilgilerini belirli koşullarda uygulama şeklini oluşturduğundan, gelecekteki başarımızı ve etkinliğimizi tahmin etmeye de yardımc1 olabilmektedir (De Weerdt \& Rossi, 2012:146). Duygusal zekâ boyutlarını ölçebilmek için bir EQ-i oluşturdu. Bar-On duygusal zekâ düzeyini ölçebilmek için kişisel süreç, kişilerarası beceri, uyumluluk, stres yönetimi ve genel ruh hali olmak üzere beş temel boyut oluşturmuştur. Tablo 1'de Reauven Bar-On' un duygusal zekâ modeli açıklanmıştır. 
Tablo1: Reauven Bar-On' un Duygusal Zekâ Modeli

\begin{tabular}{|c|c|}
\hline 1.Bo & in kendini tanımayabilmesi ve anlatabilmesi \\
\hline & $\begin{array}{l}\text { - Benlik Saygısı: Kendini doğru algılamak, anlamak ve kabul } \\
\text { etmesidir. } \\
\text { - Duygusal bilinç: Kendi duygularının farkında olmaktır. } \\
\text { - Atılganlık: Kişinin duygularının farkında olmak ve anlamaktır. } \\
\text { - Bağımsız olma durumu: Kişinin duygularını ve kendini etkili ve } \\
\text { yapıcı bir şekilde ifade etmektir. Kendine güvenmek ve } \\
\text { başkalarına duygusal bağımlılıktan kurtulmaktır. } \\
\text { - Kendini gerçekleştirme: Kişisel hedeflere ulaşmak ve } \\
\text { potansiyelini gerçekleştirmek için çabalamaktır. }\end{array}$ \\
\hline \multirow{2}{*}{ 2.Boyut } & Kişilerarası Beceri: Sosyal bilinci ve bireyler arasındaki ilişki \\
\hline & $\begin{array}{l}\text { - Empati kurabilme: Diğer bireylerin duygularını fark etmesi ve } \\
\text { anlayabilmesidir. } \\
\text { - Sosyal sorumluluk: Bireyin sosyal grubuyla özdeşleşmesi ve } \\
\text { diğer bireyler ile iş birliği yapmasıdır. } \\
\text { - Kişilerarası ilişki: Karşılıklı etkili ilişkiler kurmak. Bireyler ile } \\
\text { sağlıklı ilişki kurmasıdır. }\end{array}$ \\
\hline \multirow[t]{2}{*}{ 3. Boyut } & $\begin{array}{l}\text { Stres Yönetimi: Duygusal yönetimi ve duygusal kontrolü } \\
\text { sağlamasıdır. }\end{array}$ \\
\hline & $\begin{array}{l}\text { - Stres toleransı: Duyguları başarılı ve etkili bir şekilde yön } \\
\text { verebilmesidir. } \\
\text { - Darbe kontrolü: Duyguların başarılı ve etkili bir şekilde } \\
\text { kontrolünü sağlamasıdır. }\end{array}$ \\
\hline \multirow[t]{2}{*}{ 4. Boyut } & Uyumluluk: Değişimi yönetebilme becerisi \\
\hline & $\begin{array}{l}\text { - Gerçeklik testi: Birey kendi fikirlerini ve duygularını dış } \\
\text { gerçeklikle objektif olarak doğrulamasıdır. } \\
\text { - } \\
\text { Esneklik: Birey kendi fikirlerini ve duygularını yeni koşullara } \\
\text { göre ayarlamasıdır. } \\
\text { - Problem çözme: Kişisel ve kişilerarası problemlere karşı başarılı } \\
\text { bir çözüm üretmesi ve problemi ortadan kaldırmasıdır. }\end{array}$ \\
\hline \multirow[t]{2}{*}{ 5. Boyut } & Genel Ruh Hali: Motivasyonunu yükseltebilmesidir. \\
\hline & $\begin{array}{l}\text { - İyimserlik: pozitif olabilmektir. Hayata pozitif bir bakış acısı ile } \\
\text { bakmaktır. } \\
\text { - Mutluluk: Kendisiyle, başkalarıyla ve genellikle hayat ile barışık } \\
\text { olup mutu olmaktır. }\end{array}$ \\
\hline
\end{tabular}

Kaynak: (Bar-on, 2006:23).

\section{Cooper ve Sawaf Duygusal Zekâ Modeli}

Cooper ve Sawaf, duygusal zekâ araştırmasında kurum bazından ele alarak çeşitli boyutlar tasarlanmıştır. Cooper ve Sawaf, duygusal zekâ modelini oluştururken duygusal zekânın liderlik sürecinde nasıl etki edeceğine dikkat etmişlerdir. Bu neden ile duygusal zekâ için geliştirdikleri modelde liderlik ön plana çıkmaktadır. Cooper ve Sawaf' modelin dört bölümden oluştuğunu belirtmiştir (Cooper \& Sawaf,1998). Duygusal zekâ boyutlarına adlandırılırken duygusal zekânın dört taşı olarak ifade edilmiştir. Tablo 2'de detaylı olarak açıklanmıştır. Dört köşe taşının alt boyutlarının olduğunu da belirtilmiştir (Cooper \& Sawaf,1998).

Tablo2: Cooper ve Sawaf duygusal Zekâ Modeli

1.Köşe Taşı Duygusal Okuryazarlık: Duygusal zekânın ne olduğunu ne anlama geldiğini, tarih boyunca nasıl şekillendiği, hayatımızın 


\begin{tabular}{|c|c|}
\hline & $\begin{array}{l}\text { hangi alanlarında yararlı olduğunu anlayabilmektedir. Hayatına yön } \\
\text { verirken duygusal zekânın rehberliğini önemsenmesidir. }\end{array}$ \\
\hline & 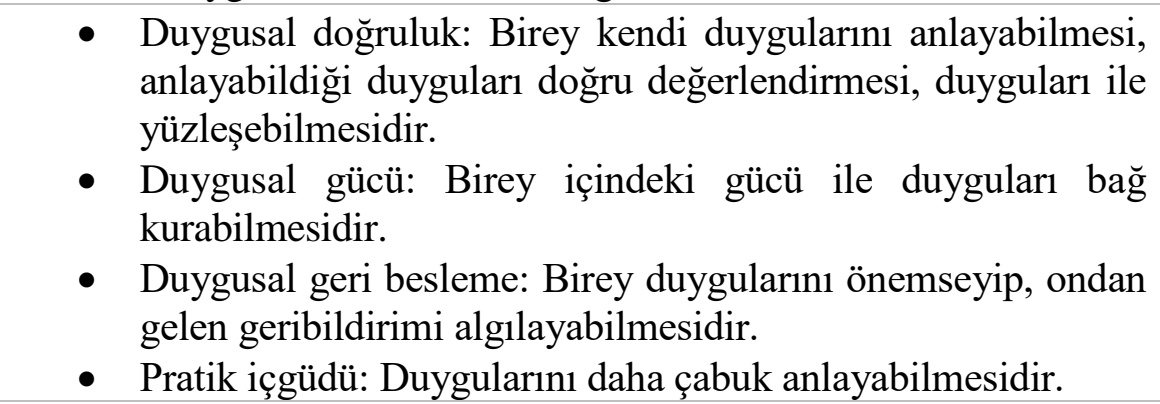 \\
\hline \multirow[t]{2}{*}{ 2.Köşe Taşı } & $\begin{array}{l}\text { Duygusal Canlılık: Duygusal canlılığı, sağlamlığı ve dinçliği } \\
\text { ilerletmek anlamındadır. Problemleri anlamaya çalışma ve çözüm } \\
\text { üretme kabiliyetini geliştirir. }\end{array}$ \\
\hline & $\begin{array}{l}\text { - Otantik varlığı: Kişinin duygusal kişiliğini tanımlar. } \\
\text { - Güven alanı: Oluşturulan güven aralığıdır. } \\
\text { - Oluşturan huzursuzluk: Huzursuzluğun oluşmasına yol açan } \\
\text { durumlar için çözüm üretilmesidir. Huzursuzluk yaratan } \\
\text { kişinin durumu düzeltmesidir. } \\
\text { - Esneklik ve yenilenme durumu: Bireyin beklemediği bir } \\
\text { durum ile karşılaştığında, bu durumu olağan karşılayıp uygun } \\
\text { bir şekilde davranabilmesidir. }\end{array}$ \\
\hline 3. Köşe Taşı & $\begin{array}{l}\text { Duygusal Yoğunluk: Bireyin hem özel hem de çalışma hayatının } \\
\text { amaçlarını uyumlaştırmasıdır. Duygusal derinliği oluşturan altı } \\
\text { yeterliliği geliştirmesidir. }\end{array}$ \\
\hline & $\begin{array}{l}\text { - Benzersiz potansiyel ve gaye: Birey istediği amaçlarını } \\
\text { değerlendirip, uygun ve doğru bir şekilde seçmesi, bireysel } \\
\text { kabiliyetlerini keşfetmesidir. } \\
\text { - İlgide bütünlük: Birey amaçlarına doğru odaklanmasıdır. } \\
\text { Odak noktası amaçlarını yerine getirmek üzerinedir. } \\
\text { - Bağlılık, hesap verebilirlik ve vicdan: Bireyin çevresindeki } \\
\text { bireyler ile ilişkisi ve farklı kültürlerden olan iki toplumun } \\
\text { ilişkilerine yön verebilmesidir. } \\
\text { - Yetki sahip olmadan etkileme: Bireye yetki veya sorumluluk } \\
\text { verilmemesine rağmen başkalarını etkileyebilmesidir. Yön } \\
\text { gösterebilmesidir. }\end{array}$ \\
\hline \multirow[t]{2}{*}{ 4.Köşe Taşı } & $\begin{array}{l}\text { Duyusal Simya: Birey karşısına çıkan sorunlarla baş edebilmeyi } \\
\text { sağlar. }\end{array}$ \\
\hline & $\begin{array}{l}\text { - Sezgi süreci: Birey atılgan olarak, yeteneklerini } \\
\text { geliştirmesine ve gelecekle ilgili karşısında çıabilecek } \\
\text { tehlikeleri durumları firsata dönüş̧ürmesine katkı sağlar. } \\
\text { - Değişimi düşünce ile gerçekleştirme: Birey hayal ederek, } \\
\text { bulunduğu anı, geride bıraktığı zaman ve gelecek ile ilgili } \\
\text { zihninde plan yapmasıdır. } \\
\text { - Firsatı algılayabilme: Bireyin sezgilerine ve duygularına } \\
\text { kulak vermesidir. Önemli olanakları yakalayabilmesidir. } \\
\text { - Geleceği oluşturmak: Birey gelecekte olabilecekleri yön } \\
\text { verebileceğine sağlayabileceğini anlayabilmesidir. Katkıda } \\
\text { bulunması gerektiğini bilmesidir. }\end{array}$ \\
\hline
\end{tabular}

Kaynak: (Cooper \& Sawaf,1998). 


\section{Goleman, Boyatzis ve Mckee Duygusal Zekâ Modeli}

Daniel Goleman'a (2011) göre duygusal zekâ; duygulardan akla uygun ve doğru bir şekilde yararlanmaktır. Engellerin üstesinden gelebilme, empati niteliklerini kullanabilme, içsel olarak kendisini eyleme yöneltmektir. Goleman, duygusal zekânın karakter ile bağlantılı olduğunu savunmaktadır (Goleman, 2011). Daniel Goleman geliştirdiği duygusal zekânın modelini ilk olarak beş boyuta ayırmıştır. Nitekim, 2002 yılında Richard Boyatzis ve Annie Mckee ile yayınladıkları yeni liderler adlı kitabında duygusal zekâ modeli üzerinde değişiklik yaparak liderlik bazında dört alana indirgemiştir. Liderlik kapsamında oluşturan duygusal zekâ modeli, dört boyutu ve on sekiz alt boyut yeterliliğinden oluşmaktadır. Daniel Goleman ve arkadaşları liderliği kişisel yeterlilik ve sosyal yeterlilik olmak üzere iki başlığa ayırmıştır (Goleman, Boyatzis \& Mckee ,2002). Duygusal zekâ için modeli için oluşturduğu dört boyut ECI adlı bir ölçek ile analiz edilmektedir (Goleman, 2011). Goleman duygusal zekâ için oluşturduğu model Tablo 3'de detaylı görülmektedir. Bu model de çalışma hayatında uygulanabilirliğinin önemi belirtmiştir (Güneş, 2016:26).

Tablo 3: Daniel Goleman, Boyatzis ve Mckee Duygusal Zekâ Modeli

Kişisel yeterliliğe sahip olma: Bu yeterlilikler kendimizi nasıl yönlendirdiğimiz belirler.

\begin{tabular}{|c|c|}
\hline $\begin{array}{l}\text { Kişisel } \\
\text { Farkındalık }\end{array}$ & $\begin{array}{l}\text { Duygusal Farkındalık: Bireyin kendi duygularını anlaması, } \\
\text { karar süreçlerinde duygularını yol haritası olarak } \\
\text { yararlanabilmesidir. } \\
\text { - Kendini doğru değerlendirme: Birey güçlü becerilerini ve uç } \\
\text { noktalarını farkına varmasıdır. } \\
\text { Kendine güveni: Bireyin kendi önemini ve yetenekleri ile } \\
\text { ilgili bilgi seviyesi yüksektir. }\end{array}$ \\
\hline $\begin{array}{l}\text { Kendini } \\
\text { Yönetebilme }\end{array}$ & $\begin{array}{l}\text { - Duygularını yönetebilme: Bireyi huzursuz eden duygu ve } \\
\text { davranışları kontrol altında tutabilmek. } \\
\text { - Şeffaflık: Güvenilir ve dürüst olma durumu } \\
\text { - Uyumlu olma durumu: Bireyin değişen koşullara karşı } \\
\text { - } \quad \text { Byumlu olmaşı ve aksaklıkların üstesinden gelme durumu } \\
\text { - İnisiyatif sahibi olma: Harekete geçip fırsatları elde etmeye } \\
\text { istekli olmak. } \\
\text { - İyimser olma durumu: durumlara pozitif bir bakış acısı ile } \\
\text { bakmak. }\end{array}$ \\
\hline
\end{tabular}

Sosyal yeterliliğe sahip olma: $\mathrm{Bu}$ yeterlilikler ilişkilerin üstesinden gelebilme düzeyini belirler.

- Empati niteliklerine sahip olma: Diğer bireylerin duygularını farkına varmak, kendini bireylerin yerine koyabilmesi,

Sosyal Tedirginliğini farkına varmasıdır.

Farkındalık • Örgütsel bazda farkındalık: Güncel konuları, karar sistemini ve kurumsal siyaseti anlayabilmek.

- Hizmet odaklı olma: İzleyicilerin, hizmet satın alan alıcıların tedarik sağlayanların ihtiyaçlarını anlamak ve yerine getirmektir.

- Esin oluşturabilme: dikkat çeken vizyon ile rehberlik etmek, istekleri artırmak.

- Etkilemek: Farklı ikna yöntemlerinden yararlanabilmek.

İlişkiye Yön Verebilme
- Diğer bireylerin gelișmesini sağlamak: Bireylere geri dönüler yapmak ve yol göstererek bireylerini kabiliyetlerini ve becerilerini geliştirmek

- Değişim katalizörlüğü: farklı bir yöne doğru hareket 
edebilmek, liderliğini sergileyebilmek ve yön verebilmektir.

- Çatışmaya yön verebilmek: Ortaya çıkan problemleri çözüme ulaştırabilmek.

- Ekip çalışması ve iş birliği: İletişimden oluşan bir sistem oluşturmak, çalışma birliğini sağlayabilmek ve ekip oluşturmaktır.

Kaynak: (Goleman, Boyatzis \& Mckee, 2002: 47-67).

Tablo 3'te görüldüğü üzere duygusal zekâ, kurum hayatını da etkilemektedir. Kurumda çalışan birey, fikirlerini ve görüşlerini iş arkadaşlarına rahatlıkla belirtebiliyorsa, birbirilerini yapıcı düşüncelerini belirterek eleştiri yapabiliyorsa ve bundan kimse rahatsız duymuyorsa, kurumda çalışma birliği ve dayanışma sağlanabiliyorsa, bireyler girişimciliği önemsiyor ve destekliyorsa, kurum ile özdeşleşebiliyorsa, bu kurumda duygusal zekâ ruhu var demektir (Doğan \& Demiral, 2007:221). Duygusal zekâyı benimseyen kurumlar, gelişme firsatı sağlayan eleştirel fikirlerin önemsendiği, gerçeği yansıtan ve şeffaflığın ilke veya kural olarak görüldüğü bir kurum kültürüne sahip olmaktadır. Böyle kurumlarda, değişimin desteklenmesi, çevreye duyarlılık, güven, bağlılık, topluma karşı duyarlı olma, esneklik, iki yönlü iletişim gibi konular değer kazanmaktadır (Çay, 2009:55). Duygusal zekâ çalışma ortamındaki huzursuzluğu ve buna benzer etkenleri azaltmaya yönelik plan yapma ve pozitif bir çalışma atmosferi oluşturmak için fikir belirtme, duygular hakkında bilgi edinme, duygulara göre davranış sergileme yeteneği, kurumda üst yönetimde olması gerekmektedir. Değişimin üstesinden gelebilme, değişime uyumlu olabilme, karar verme sürecinde çelişkili hareket etmemesini sağlayan özellikler duygusal zekâ ile yönetilmektedir (Arıcıŏglu, 2002:29).

Duygu kavramı ise hayatımız boyunca karşımıza çıkabilecek durumlarda doğru bir şekilde karar verebilmek için kilit rol üstlenmektedir. Bireyin içinde bulunduğu durumda vereceği tepkileri, yaşamak istediği yeri, hangi alanda çalışmak isteyeceği gibi seçim gerektiren konularda duyguların katkıları daha çok büyüktür. Birey hayatında karşısına çıkan seçimleri yapabilmesi için sezgilerinden, hislerinden ve hayattaki tecrübelerinden oluşan bir duygu kütüphanesine ihtiyaç duymaktadır (Tuğrul, 1999:14). Duygularına önem vermek, duygusal bağ kurmaya, daha çok insani niteliklere önem vermeye, güvenilir bir birey olmaya, değişime karşı pozitif bir bakış acısı geliştirmeyi sağlar. Yaşamdaki etik davranışların temeli duygusal anlamda becerili olmak ile bağlantılıdır (Acar, 2001:22). Günümüzde uygun ve doğru kabul edilen davranışlarımızın temelinde duygusal yetenekler vardır. Duygusal yetenekler, bireyler arası iletişim becerisine sahip olan, kim olduğunu bilmesini sağlayan, çevresinde yaşanan durumlara karşı duyarlı olan, negatif duygulara kontrol edebilen, içindeki gücü yeniliğe doğru yönlendirebilen kişilerde bulunan yetenektir. Bu duygusal anlamda yeterliliği olan kişilerin sergileyeceği davranışlardır. Duygusal anlamda olgun olmak, bireylere karşı ve yaşadığı hayatta karşı pozitif hissetmek için çeşitli yollar bulmayı sağlamaktadır. Duygusal zekâ ile doğru tutum sergileyen, kim olduğunu ve hayattan ne istediğini bilen bir birey olmak için firsat sağlamaktadır (Abuamer, 2016:24).

\section{Liderlik Tanımı ve Liderlik Özellikleri}

Lider kavramının 1983 tarihinde yayımlanan Oxford İngilizce sözlüğünde yer aldığı ve 19. yüzyılda basılmış olan kitap kaynaklarında ortaya çıktığı görülmüştür. Lider kavramı, ilk önce İngilizce dilinde liderlik kavramı olarak ele alınmış ve açıklanmaya çalışılmıştır (Kelsay, 2010:5). Liderlik, uzun yıllar boyunca çok konuşulan ve çok fazla araştırma yapılan konular arasından yer alan bir kavramdır. Liderlik kavramının, beş bin yıl önce Mısır'da bulunan hiyeroglif yazı sistemi ile yazılmış tarihi yazıtlardan eski bir kavram olduğu anlaşılmaktadır. Yunan filozofları olarak bilinen Aristo ve Plato'un milattan sonra üç yüz ve dört yüz yıllarında yapılan araştırmalarda liderlikle ilgili yapılan açıklamalar yer almaktadır (Aslan, 2013:25). Liderlik kavramı, ulaşılmak istenilen hedefleri elde edebilmek için, bireyleri bir araya getirebilme ve ekip halinde yön verebilme yeteneğidir. Bireyleri anlayabilme, bireyleri analiz edebilme, tepkilerini önceden fark edebilme, bireyleri kontrol edebilme yeteneğini kapsamaktadır (Özdemir, 2013:3).

Liderlik kavramının kelime anlamı incelendiğinde yoluculuk halinde olan, bir duruma veya olguya rehberlik yapmak olarak belirtilmektedir. Bireylerden oluşan toplulukların birlikte yaşam 
sürdürebilmesine, farklı fikirler üreten bireylerin ortak ve büyük hedef için bir araya gelmeleri ve bu hedefi gerçekleştirmeye çalışması yönünde bireyleri etki altına alabilecek bir süreçtir (Taşkıran \& Köse, 2016:570). Liderlik, kararlaştırılmış koşullarda, belirlenmiş bireysel veya ekip hedeflerine ulaşılabilmesi için, bireyin hareketlerini etkilemesi ve yön tayin etmesidir (Tengilimoğlu, 2005: 2). Liderlik, kurumun amaçlarına ulaşması için, kurum çalışanlarının ihtiyaçlarına, çevrenin, ekiplerin ve bireylerin arasındaki iletişimine düzen veren, bölümler ve bireyler arasında etkileşimi ve iletişimi oluşturan bir süreçtir (Özsalmanlı, 2005:138). Bir başka tanımda liderlik, bireyleri ortak hedefler doğrultunda yönetebilme becerisine ve isteğine sahip olup, bireysel ve dinamik süreç olarak belirtilmektedir. (Yörük \& Dündar :96). Yapılan tanımlardan da anlaşılacağı üzere liderlik, kritik süreçlere, kurum kültür, hedef, strateji, ana kimlik gibi kurumun sürdürebilirliğini sağlayan mantıklı ve üzerinde düşünülmüş eylemleri yönetmek, geleceği şekillendirmek üzere etkiler oluşturmak için önemli bir aktördür (Geçikli, 2012:23). Bu doğrultuda liderlik, bireyleri saptanmış hedeflere doğru hareket etmesini sağlayabilmek için ikna etme yeteneğini kullanmaktadır. Lideri takip eden bireylerin amaçlarına ulaşabilmesi için eyleme geçebilmelerini sağlamak, liderin sahip olduğu becerilerin ve yeteneklerin tümü olarak ifade edilmektedir (Bakan \& Büyükbeşe, 2010:74). Genel olarak liderlik kavramını açıklamak amacı için yapılan tanımlamalara bakıldığında benzerlikler görülmektedir.

Lider, liderlik sürecini etkili ve başarılı bir şekilde gerçekleştirip bu başarı düzeyini devam ettirmek istiyorsa sahip olması gereken birtakım nitelikler vardır. Liderin yaratıcılık, beklenmeyen durumlara hazır olma, içsel cesaret, risk alabilme, durumları ve olayları hızlı kavrayabilme yeteneği, çözüm üretme, yenilikleri uygulayabilme becerisi, serinkanlılık, sezgi gücü, taktik, stratejik düzeyde bilgi ve uygulama kabiliyeti gibi niteliklerini kullanması gerekmektedir (Erdal, 2007:8). Öncelikle bireylerin lidere inanmaları gerekmektedir. İnanılırlık niteliği ile, lideri takip eden bireylerin, lideri uygun görüp kabullenmelerini sağlar. Liderin takip edilebilmesi için kabullenme önemli neden olarak gösterilmektedir. Aynı zamanda liderin kurumun amaçlarına ulaşabilmesi ve bireylerin üzerinde olumlu bir etki sağlayabilmesi için önemlidir. Lider, aynı zamanda dinleyici olmalıdır. Liderin dinleme yeteneğinin olması karşısındaki bireylere verdiği değeri ifade etmektedir. Lider empati kurarak veya dinleyerek etkileme niteliği de kazanmaktadır. Lider söylediklerini ve verdiği kararı yerine getirebilmesi için etkileyebilme özelliği olması gerekmektedir (Şimşek, 2019:8). Bununla birlikte, liderin kavramsal yeteneklerini sergileyebilmesi gerekmektedir. Kavramsal yetenek ile stratejik fikir süreci ile stratejik unsurlar oluşturabilir ve kurumsal amaçlara ulaşabilir. Bir başka önemli nokta ise liderin güvenilirlik unsurunu benimsemesidir. Güvenilirlik niteliği liderin saygınlığını ve imajını oluşturmaktadır. Bireylerin güvenini kaybeden liderin, bireylere yön verebilmesi başarısılık ile sonuçlanmaktadır. Nitekim güvenin oluşturulduğu ortamda hem lider hem de çalışan bireyler ortak hedeflere ulaşabilir. (Bektaş, 2016:44). Bu doğrultuda lider, bireylere rehberlik eden ve yön veren olmalıdır. Lider takipçilerini etki altına alabilmesi için duygu okur yazarlığına sahip olmalıdır. Çeşitli duyguları hissedebilmeli ve daha fazla takipçilerinin duygularına hitap etmelidir (Acar, 2002:12).

\section{Liderlikte Duygusal Zekânın Değeri}

Başarılı ve başarısız bir lideri belirleyebilmek için liderin duygusal yetkinliğine dikkat edilmesi gerekir. Liderin bir konudaki görüşlerini, konunun onun için ne ifade ettiğini, tedirginliğini ve duygularının farkına varılması önemlidir. Lider kendi hareketlerini ve tutumlarını, akıl yürütmesini sorgular, diğer bireyleri ile benzer şekilde anlayabilmeye çalışır. Bu doğrultuda kişiler arası ilişkilerde etkili olmaktadır. Bireylerin dinleyebilmesi ve anlayabilmesi için açık bir iletişim kuran, bireylerin görüşlerini dikkatle dinleyen liderler başarılı ve etkili olabilecektir (Geçikli, 2012: 26-27).

Liderlikte yüksek oranda sosyal kavrayış, etkili bir duygu yönetimi ve hassasiyete ihtiyaç duyulmaktadır. Liderden, stratejik bir proje yönetimi gibi liderlik görevlerine ek olarak, bireylerin motivasyonunu yükseltme, bireylerin fikir üretmesine, ilham verme, çalışma ortamında olumlu katk1 sağlayacak davranışlar geliştirme, itibar algısı ve etkili bir katılım sağlanması gibi beklentiler vardır. Liderin bütün bu gayretlerin sonucunda duygusal zekâ becerisi önemli bir destek noktasıdır. Liderin duygusal zekâ kavramının temel noktasını oluşturan bireysel ve sosyal dinamiklerine yön verebilme becerisine artan ilgi, kurumda duyguların oldukça önemli bir rolü olduğunu belirtmektedir (Edizler, 2010:140).

Çalışma hayatında duygusal zekâya sahip lider birleştirici, ikna edici ve güdüleyicidir. Lider kendi davranışlarını diğer bireylere nasıl etki ettiğini anlayabilir ve gerektiği durumlarda kendi ve diğer 
bireylerin duygularına yön verebilmektedir. $\mathrm{Bu}$ kabiliyetlere sahip olan lider, ekibin duygusal parlamalarını kurumun amacına ulaşmasını sağlayacak şekilde dönüştürür. Bireylere fikir üretebilmesi için ilham verir. Bireylere değerli ve güvende olduklarını hissettirir (Aysel, 2006:104). Liderin duygusal zekâ bakımından olgunlaşması ile elde ettiği niteliklerin liderlik etkinliğinde önemli olduğu anlaşılmaktadır. Bu nitelikler (Güneş, 2011:92),

- Görevde hata risk oranı fazla olsa bile bu görevi bireylerin yerine getirebileceğine güvenilmesi,

- Görevi yerine getirirken takdir edilebilme düşüncesi olmadan görevi başarı ile yerine getirebilmesi,

- Bireyler arası ilişkide oluşan bir sorunda aralarındaki geçmiş olayları görmezden gelerek o an ki soruna odaklanabilmesi,

- Bireylerin niteliklerini ve özelliklerini olduğu gibi kabul edebilmesi,

- Lidere, iletişimi olan bireyler ve iletişimi olmayan bireylere karşı sergilenen nezaketi benzerini sergileyen bireyi değerlendirebilmesidir.

Duygusal olarak farkındalığı yüksek olan lider, iç sesinden yararlanarak denge kurmaktadır. Bu durum hislerinin sergilediği performansı ne derece etkilediğini ve kendini nasıl yönettiğinin farkına varmasını sağlamaktadır. Duygularını anlayan birey ile lider hangi yollardan nasıl geçeceğini daha iyi anlayabilmektedir. Hangi kabiliyetlere sahip olduğunu veya hangi kabiliyetlere sahip olmadığı bilen lider daha doğru kararlar verebilmektedir (Şahinkaya, 2006:66-67). Benzer şekilde, ekibin amaçlara ulaşabilmesine katkı sağlayabilmesi liderin sahip olduğu duygusal zekâ düzeyi ile bağlantılıdır. Duygusal anlamda zeki olan liderin ekibindeki bireylerde huzurlu bir atmosfer vardır. Düşünceler rahatlıkla belirtilerek sonuçlar çıkartılmaktadır. Birlik içerisinde kararlar alınır ve görevler başarılı bir şekilde yerine getirilmektedir. Değişim ve belirsizlik sürecinde duygusal bağ kurularak odaklanmaları sağlanır. Diğer bireyler kurulan duygusal bağ ile görevlerini yerine getirmek için adım atarlar. Başarılan görevin tatmini ile ekip halinde hareket ederek yeni görevlere odaklanırlar (Goleman, Boyatzis \& Mckee, 2002: 32-33).

\section{Duygusal Zekâsı Yüksek Liderlerin Özellikleri}

Liderlik sürecinde duygusal zekânın olumlu katkısının olduğunun anlaşılması sonucunda, liderlerin var olan yeteneklerine ek olarak duygusal zekâya ait yetenekleri elinde bulundurması ve uygulaması istenmektedir. Duygusal zekâ liderlik sürecindeki önemli olmasının nedeni çalışma hayatında etkililiğini olumlu yönde etkileyen zekâ ve benlikten kendini ayırarak yaşam boyu geliştirebilir olmasıdır (Erkuş \& Günlü, 2008:192). Daniel Goleman, Richard Boyatzis ve Annie Mckee yazdıkları "Yeni Liderler" adlı kitabında liderin duygusal zekâ niteliklerini ortaya çıkartabilmesine katkı sağlayan yeterlilikleri belirtmektedir (Goleman vd., 2002).

\section{Kişisel Farkındalık}

Yüksek duygusal zekâya sahip olmanın sağladığı önemli niteliklerden ilki duygusal farkındalıktır. Duygusal zekâlı liderin duygusal farkındalıkları yüksek olmaktadır. Lider duygularının, çalışma sürecinde sergilediği performansına ve kendisine ne derecede etkilediği hakkında bilgi sahibidir. Kendisine rehberlik eden inançlarına karşı bağlı olurlar. Duygusal farkındalık bireyleri yönetebilme niteliğgi kazandırır (Güneş, 2016:94-95). Duygusal farkındalığı yüksek olan lider bulunduğu ortamın duygu durumunu analiz eder ve ortama göre duygu durumunu ayarlayabilmektedir. Böylece kurulan iletişimin başarılı bir şekilde sürdürebilirliğini sağlamış olur (Acar, 2001:38). Duygusal zekânın yüksek olması ile lider kendini doğru değerlendirebilmektedir. Kendini doğru değerlendirebilen lider güçlü ve geliştirilmesi gereken taraflarını hakkında bilgi sahibidir. Zayıf yönlerine odaklanarak, bu zayıf yönlerini olumlu bir geri bildirim olarak görmektedir (Güneş, 2016: 94-95). Başarılı bir sonuç elde edemediği zaman bahane üretmezler, takıntı hale getirmezler ve sıkıntı çekmeden sindirebilirler (Aysel, 2006:99). Liderin, kişisel farkındalık başlığı altında elde ettiği bir diğer nitelik ise kendine güven duymasıdır. Özgüvenli lider duygularını anlayıp, doğru bir ifadeler ile anlatabilmek ve geliştirilmesi gereken kabiliyetlerini ve etkili niteliklerini farkında olup kendilerine rehberlik ederler (Acar, 2001:41-42). Sıkıntının yoğun ve stresin yoğun olduğu zamanlarda karar verirken ve kararları 
hayata geçirmeye çalışırken kendinden emindirler. Özgüveni olmayan liderler, zor durumlarda atılgan olabilmesini sağlayan bir özelliktir (Geçikli, 2012:28).

\section{Kendini Yönetebilme}

Duygusal zekâsı yüksek olan liderin, duygusal öz yönetim düzeyi yüksek olmaktadır. Duygularının kontrolünü sağlayan lider, kendisini huzursuz eden olumsuz duygularını yönetebilmektir. Liderin kendisini yönetebilmesi olumsuz duygularından fayda elde edebilmek için etkili yön vermesidir. Öz yönetimi sağlayan lider, zorluğun ve sıkıntıların düzeyi yoğun olduğu dönemde, serinkanlılığını koruyup, sakinliğini koruyup dinç bir zihin ile fikir üretebilir (Aysel, 2006:100). Bir soruna karş1 çözüm üretirken, kendi duygularına ve fikirlerini kontrolü altında tutabilmesini, kendini negatif duygularının kaynağı olarak görmeden ve olumsuz fikirleri etkisinin altında kalmadan yapıcı müdahale edebilme kabiliyeti sağlamaktadır (Delice \& Günbeyi, 2013:214). Kendini yönetebilen lider şeffaflığı benimseyen liderdir. Bu doğrultuda, şeffaf olan liderler, değerlerini yaşamında uygulayabilmektedir. Liderin saydam olması demek, duygu, davranış ve inançlarını sergilerken diğer bireylere karşı şeffaf olması anlamına gelmektedir. Liderin şeffaf olması kendine ve diğer bireylere dürüst ve açık olabilmesidir. Bununla birlikte hatalara 1lımlı olarak yaklaşmasıdır. Toplumun kabul ettiği davranışlara aykırı davranan bireyleri görmezden gelmemektedirler (Goleman vd., 2002). Duygusal zekâsı yüksek olan liderin uyumluluğu da yüksek olmaktadır. İçsel gücünü kaybetmeden ihtiyaçları veya gereksinimleri başarılı bir şekilde sonuçlandırabilmektedir. Kurum hayatının bir parçası olan belirsizliğe karşı olumsuz bir tutum takınmazlar. Uyumluluk olan lider değişime karşı direnç göstermeyip, değişime karşı 1lımlı yaklaşarak uyum sağlamaktadırlar. Yeni ve farklı bilgilere ulaştı̆̆ında hızlı bir şekilde fikir yürütebilme yeteneğine sahiptir (Şahinkaya, 2006: 67).

Duygusal zekâya sahip olması liderin, başarıya ulaşabilmesi için harekete geçmesini sağlar. Başarı dürtüsü ile lider gerçekleştirmek istediği hedefi tanımlayarak, hedefe ulaşabilmek için içindeki potansiyel gücünü ortaya çıkarıp başarıya doğru ilerler. Liderin içindeki bu istek, kurumda hangi kademede olursa olsun, sergilediği performansın daha çok yükselmesine olanak sağlamaktadır. Duygusal zekâ ile kendini yönetebilen lider inisiyatif sahibidir. Yeni fikirler üretebilmek için elverişli ve uygun durumları algılaması, zorluklarla karşı karşıya kaldığında vazgeçmeyerek, bu durumu firsat haline dönüştürerek yararlanması liderin diğer önemli özelliklerindendir (Sönmez, 2010:43-44). Duygusal zekâsı yüksek olan liderin iyimserliği de yüksek olur. Bu yönü, sıkıntılı ve aşılması güç olan durumlarda tedirgin olmamasını veya bu zorluğa boyun eğmemesini sağlar. $\mathrm{Bu}$ doğrultuda, lider karşılaştığı zorlukların üstesinden geleceğini düşünerek, hayata karşı pozitif bir bakış açısında bulunur (Somuncuoğlu, 2005:276).

\section{Sosyal Farkındalık}

Sosyal farkındalığı yüksek olan liderin empati kurabilmesi de yüksektir. Lider, kendini diğer bireylerin yerine koyarak diğer bireylerin duygu durumlarını algılayabilmektedir. Empati beceri gelișmiş olan liderin iletişim kurabilmesi ve bilgi edinebilmesi için bireyleri etkili bir şekilde dinleyebilmesini gerekir. Önyargıyı göz ardı ederek bireylerin gereksinimlerini ve isteklerini anlayarak, olaylara veya durumlara onların görüş açısından bakabilmektedir (Delice \& Günbeyi, 2013:214).

Duygusal zekâya sahip olmanın kazandırdığ 1 bir diğer nitelik ise kurumsal farkındalıktır. Duygusal zekâsı yüksek olan liderin kurumsal farkındalığı da vardır. Bu doğrultuda lider kurumun bireylere olan beklentilerinin farkındadır. Kurumun misyonu, vizyonu, kültürü ve değerleri hakkında çalışanları bilinçlendirerek, bütünleşmeyi sağlamaktadır. Böylelikle lider bireyleri hedefe kolay bir şekilde hedefe yöneltebilecek ve yerine getirdiği görevi ile ilgili çelişki yaşamayacaktır (Aysel, 2006:102). Duygusal zekâ ile lider hizmet odaklı olmaktadır. Hizmeti satın alanlar ile olumlu sürdürebilir bir iletişim sağlayabilmesi için duygusal iklim oluşturmaktadır (Goleman, Boyatzis \& Mckee, 2002).

\section{İlişkiye Yön Verebilmek}

Lider ilişkiye yön vererek bireylerin dikkatini çekip ortak misyon ve vizyon doğrultusunda ilk adımı atmasını sağlamaktadır. Böylelikle uyum oluşturur. Bu sayede liderler, diğer bireylerin taleplerinin simgesi olmaktadır (Goleman, Boyatzis \& Mckee, 2002). Duygusal zekâlı lider ilişkiye yön vererek 
etkileyebilme niteliği sergileyebilmektedir. Etki oluşturan lider bireyleri ikna edebilme konusunda uzman olurlar. Etkileyebilme düzeyi yüksek olan lider, mantığa hitap eden lider hangi zaman periyodunda olumlu sonuçlar elde edeceğini bilir. Hangi zaman aralığında talepte bulunması gerektiğini de bilmektedir (Çay, 2009:66). Duygusal zekâ anlamında gelişmiş lider değişim katalizörüdür. Değişimin gerçekleşmesini engelleyen engelleri ortadan kaldırırlar. Mevcut durumda değişimin gerekli olduğunun ifade edilmesinden de çekinmezler. Değişim sırasında ise çevresine katkıda bulunarak, diğer topluklara ve değişimin ihtiyaç olduğu durumlarda model ve katalizör görevi yapmaktadır (Şit, 2019:68).

\section{Duygusal Zekâsı Yüksek Olan Liderin Örgüte Etkileri}

Duygusal zekâsı yüksek olan lider, ekip ruhunu oluşturarak, ekip üyelerinin birbirilerine olan bağlılı̆̆ını artırmaktadır. Böylelikle, ekip üyelerinin birbirlerine destek olmalarını sağlayarak, bireylerin verimli ve gönüllü olarak katılımını sağlarlar (Güneş, 2016: 104-106). Bu doğrultuda, kurum içerisinde sağlıklı bir iş birliği olması, çalışanın devamlılığına, kurumun diğer üyeleri ile uyumlu olmasına, kurumun verimliliği ve kurum dayanışmasının sağlamasında kritik rol oynamaktadır (Sönmez, 2018:47). Bir başka özelliği de diğer bireyleri geliştirmeye çalışmasıdır. Bireylerin başarılarını taktir ederler ve ödüllendirirler. Bununla birlikte, olumlu katkı sağlayanlara geri dönüşler yaparlar. Bireylere bir işte doğruyu ve iyi olanı gösterirler. Akıl okur yazarlığı gelişmiştir. Bu liderler, olumlu katkılar sağladığı bireylerin aklını iyi okur. Bu sayede başarılı bir geri dönüş yapabilirler. Aynı zamanda, performansını yükseltmek için ne zaman çalışacağını ne zaman çalışmayacağını bilirler (Çay, 2009:66). Liderin duygusal zekâya sahip olması bireyler arasında ortaya çıkan çatışmaları çözüme ulaştırmasını kolaylaştırmaktadır. Böylelikle, lider duygusal zekâ ile ortaya çıkan çatışmaları yönetebilmektedir. Etkili bir liderin sergilediği nitelik olan bu özellik sayesinde, bütün tarafların kabul edeceği çözümler üreterek çatışmaları çözümleyebilmektedir (Şenocak, 2015:37). Duygulardan kaynaklanan çözülemeyen problemler, kurumun büyümesini ve ilerlemesini olumsuz yönde etkilemektedir. Bu problemlere uygun çözümler için fikir üretme liderin sorumluluğu altındadır. Aynı zamanda liderin kurum içerisindeki etkinliği duygusal zekâ ile bağlantılıdır. Lider, müşterilerin ve çalışanların duygusal isteklerini anlayarak, değerlendirerek ve bireylere uygun tepkiler verdiği taktirde etkili olabilmektedir (Acar, 2002: 56). Duygusal zekâ ile lider, kurum üyelerinin esnekliğe yatkınlığ 1 ve daha fazla yaratıcı düşünmeleri doğrultusunda yön vererek iş tatmin düzeyini yükseltmektedir. Kurum içerisinde çalışma birliğini, uyumluluğu ve örgütsel vatandaşlık tutumlarını olumlu yönde gelişim göstermesini sağlamaktadır. Böylelikle kurum üyelerin sergilediği performansı yükselterek kuruma değer katmasına yardımcı olmaktadır. Kurum üyelerinin motive edilmesinde, bağlılığını artırılmasında, çalışan devir düzeyinin düşürülmesinde, değişime olan direncin kırılmasında ve başarılı bir iletişim ağının kurulmasında payı büyüktür (Doğan\&Demiral, 2007:225-228).

Liderin duygusal zekâ düzeyinin yüksek olması, kurumda farklı veya değişik düşüncelere sahip bireylerin duygularına yön vererek, sakin ve uzlaşma düzeyini artırarak daha durgun bir ortam oluşturmaktadır. Bu durum yeni ve farklı fikirlerin ortaya çıkmasını sağlar. Örneğin, pozitif duygulara sahip olan iş görenler daha çok umutlu olur, görüşlerini açıklıkla dile getirirler ve kendilerine güvenirler. Negatif duygu durumunda olan bireyler, karamsar, doğru olmayan verileri ve hataları ortaya çıkarmaya daha çok eğilimlidir. Lider, duygu durumları yaratıcılığı nasıl etkilediğini fark ederek hem pozitif hem de negatif duygu durumlarını yön vererek bireylerin yeni fikirleri üretmek için istekli olmasını sağlar (Cengiz, Acuner \& Baki, 2006:425-426).

Duygusal zekâ kurum içerisinde liderin, liderlik işlevlerini gerçekleştirmesine ve etkili bir liderlik sergilemesine yönelik katkıda bulunur. Duygusal zekâ ile lider (George, 2000:1039);

- Kurum içerisinde çalışan bireylerin kolektif olarak amaçlara ve hedeflere erişebilmesi için ortak duygulara ulaşmasını sağlar.

- Çalışanların görevine ait faaliyetleri ve davranışlarının önemi hakkında bilgi verir ve takdir eder.

- Kurum içerisinde çalışma birliği, güven, heyecan, coşku, iyimserliğin olduğu bir atmosfer oluşturarak ve bu atmosferi sürdürür.

- Karar verme sürecinde ve değişimde esnekliği teşvik eder.

- Kurum için anlamlı bir kimlik ortaya koyarak, kurum kimliğini sürdürür. 
Liderlik, duygusal zekâdan ibarettir. Lider, duygusal zekânın değersiz olduğuna dair tutumlar sergiler ise, kurumda duygusal zekâ ile etkileşim gerçekleşmez ve kurumun bir parçası olamaz. Böyle bir durumda, kurumda çalışan bireyler kabiliyetlerini ve becerilerini kendisine saklamaktadır. Bu doğrultuda, liderlerin duygusal zekâsının kurum ile etkileşim halinde olabilmesi için (Acar, 2001:94);

- Duygusal zekâsını kullanan liderler, kurumda çalışan bireylere örnek olurlar.

- Kurumda bireylerin duygusal zekâ kabiliyet ve becerilerini över, karşıllı olarak bireyleri ödüllendirir.

- Kurum içerisinde duygusal zekâsı olgunlaşmış bireyleri belirler.

- Duygusal zekânın kurum içerisinde gelişim göstermesine katkı sağlar.

Tüm bu açıklamalar 1şığında, liderin diğer bireylerden olan farklılığını ortaya koyan bir nitelik olarak zekâ kavramı karşımıza çıkmaktadır. Zekâ bireyleri tanıma, onları anlayabilme, sorun çözebilme, farklı fikirler üreterek, sorunlara yeni çözümler bulabilmesini sağlamaktadır. Birey böylelikle daha hızlı bilgi edinebilir. Liderin, bireyleri anlayabilmesi ve onları farklı açılardan değerlendirebilmesi için empati sahibi olmas1 gerekmektedir.

Başarısız ve etkisiz olarak nitelendirilen liderin, başarı elde edememesinin sebepleri değerlendirildiğinde ortaya çıkan sonuçta teknik anlamda yetersiz olma durundan daha çok kişiler arası ilişkilerindeki temel eksiklik olduğu görülmektedir. Araştırmacılara göre kurum başarı elde etmesini sağlayan duygusal zekâdır. Kurumda çalışan bireylerin görev ile ilgili başarıları \%80 oranında duygusal zekâ ile ilgilidir. Geri kalan \%20 oranı ise bilişsel zekâ ile ilişkili olduğu görülmektedir (Babaoğlan, 2010:122). Bu nedenle, işletmeler özellikle değişim, dönüşüm sürecinde duygusal zekâs1 yüksek liderlerin varlığına ihtiyaç duymaktadır. Duygusal zekâsı yüksek olan liderlerin çalışma yaşamında duygusal zekâsı düşük olanlara göre daha başarılı olduğunu söylemek mümkündür. Duygusal zekâsı, farkındalıkları, iç görüsü gelişmiş kişiler başkalarının duygularını anlama ve etkili iletişim kurma konusunda gerek özel gerek mesleki alanlarda daha avantajlı konuma geçerler.

\section{Liderlik ve Duygusal Zekâ Alanında Yapılmış Çalışmalar}

Liderlik ve duygusal zekâ birçok faktörden etkilenen ve yine birçok faktörü etkileyen değişkenlerdir. Bunun yanında bu iki kavramın birbirinden etkilendiği yerli ve yabancı literatürde yapılmış birçok çalışmayla ortaya konmuştur. Bu doğrultuda, Acar (2002) yapmış olduğu çalışmada, kurumda görev yapan yöneticilerin duygusal zekâ ile liderlik tutumlarının arasındaki ilişkiyi ortaya çıkarmayı amaçlamıştır. Çalışmada, Bar-On tarafından tasarlanan duygusal zekâ ölçeği kullanılmıştır.181 kişiye anket yapılmıştır. Birey odaklı liderlik tutumlarının kişisel beceri, bireyler arası beceri, uyumluluk ve genel ruh durumu duygusal zekâ boyutları ile ilişkili olduğu belirtilmiştir. Görev odaklı liderlik tutumu genel ruh hali ve uyumluluk ile ilişkili olduğu tespit edilmiştir (Acar, 2002:57-65). Aysel (2006) ise çalışmasında, kurumdaki liderlerin, kurumdaki pozisyon düzeyine, eğitim durumu, kurumdaki kıdemleri ve yaş faktörünün duygusal zekâ düzeyleri arasındaki farklılıkları belirtmeyi amaçlamıştır. Çalışma kapsamında 105 kişiye anket yapılmıştır. Çalışma sonucunda, lise ve ön lisans mezunlarının liderlerin, lisans ve lisans üstü mezunlarına göre daha düşük duygusal zekâ oranına gözlemlenmiştir. Duygusal zekâ eğitim süresi ile birlikte gelişmekte olduğu sonucuna varılmıştır. Kurum içerisinde kıdemi 16 yıl ve daha az olan liderlerin, kurumda 16 y1ldan daha fazla görev yapan lidere göre duygusal zekâ oranlarının benzer olduğu tespit edilmiştir (Aysel, 2006: 107-127). Başka bir çalışmada, Şahinkaya (2006) hava kuvvetlerinde görev yapan bireylerin duygusal zekâ boyutunu incelemiştir. Çalışmada farklı uçak tiplerinde ve filolarda çalışan 100 kişinin anketi değerlendirilmiştir. Duygusal zekâ ile mantığın birlikte kullanıldığı zaman başarılı ve etkili bir birey olunduğu sonucuna varılmıştır. Buna ek olarak, eğitim süresi uzadıkça duygusal zekâ ile birlikte liderlik niteliklerini sergileyebilmesinde de artış olmakta olduğu görülmektedir. Duygusal zekâ liderin liderliğini sergilemesini sağladığını belirtmiştir (Şahinkaya, 2006: 85-111).

Altıntaş (2009) ise çalışmasında, kurumsal amaçlar ulaşabilme ve liderlik stillerinin duygusal zekâ ile olan ilişkisini belirmeyi amaçlamıştır. Araştırmada Richard Boyatzis ve Daniel Goleman tarafından geliştirilen duygusal zekâ ölçeği kullanılmıştır. Isparta ilinde ilkokullarda görev yapan 556 öğretmene ve 46 okul müdürlerine anket yapılmıştır. Yönetici pozisyonunda görev yapan bireylerin duygusal zekâlarının kurum performansı üzerindeki katkısı üzerinde çalışılmıştır. Çalışmanın sonucunda duygusal zekânın alt boyutu olan sosyal bilincin okul müdürlerinin okul başarısını olumlu yönde 
etkilediği tespit edilmiştir. Buna ek olarak çalışmada, öğretmenlerin duygularını anlayarak, ihtiyaçları ve talepleri hakkında bilgi sahibi olunmasının, öğrencilerin başarılarına da olumlu etki oluşturduğunu belirtmiştir (Altıntaş, 2009:105-108). Çay (2009) ise çalışmasında, duygusal zekâ, liderlik ve çalışma hayatında duygusal zekâ konularını incelemiştir. Çalışma kapsamında özel sektör ve kamu sektöründe 215 kişiye anket uygulamıştır. Özel ve kamu sektöründe çalışan yönetici ve liderin duygusal zekâ oranı alt düzeyde çalışan bireylere göre daha fazla olduğu sonucuna ulaşmıştır. Çalışan eğitim, yaş, cinsiyet ve kıdem ile duygusal zekâ arasında bir farklılık bulunamamıştır. Çalışmada, duygusal zekâ ile daha başarılı bir iletişim kurulduğu ve olumlu yönde iletişimi ilerlettiği sonucuna varılmıştır. Ayrıca duygusal zekâ ile pozitif bir çalışma ortamının zemini hazırlanmakta olduğunu belirtmiştir (Çay, 2009: 92-94).

Özer (2010) yaptığı çalışmada liderlik stilleri ile duygusal zekâ ile etkileşimi belirlemeyi amaçlamıştır. Çalışmada farklı pozisyon konumlarında görev üstelen 233 bireye anket yapılmıştır. Araştırma sonucunda eğitim seviyesi baz alındığında lisans ve lisans üstü mezun olan lise ve ön lisans mezunlarına göre duygusal zekâ oranı daha yüksek ortaya çıkmıştır. Kurumda 40 yaşın üzerinde liderler, 40 yaş ve 40 yaşın altındaki liderin duygusal zekâ oranın da anlamlı bir ilişkiye ulaşılamamıştır (Özer, 2010:108-136). Delice ve Günbeyi (2013) çalışmalarında polis teşkilatında görev yapan polis liderlerin, duygusal zekâ düzeyleri ile liderlik tutumları arasında ilişkiyi araştırmışlardır. Yapılan çalışmada Bar-On duygusal zekâ ölçeği kullanılmıştır. Polis teşkilatında görev yapan farklı görev ve farklı pozisyondan 113 polise anket yapılmıştır. Çalışma sonucunda, liderlik ile duygusal zekâ ile olumlu ve kuvvetli bir ilişki olduğu tespit edilmiştir. Görev yapan liderlerin duygusal zekâ düzeyi olumlu bir şekilde artıkça liderlik tutumları da olumlu bir artış olduğu gözlemlenmiştir (Delice \& Günbeyi, 2013:219-230). İşliel 2016 yılında yürüttügü çalışmasında ise, eğitim sektöründe görev yapan yöneticilerin liderlik tutumları ile duygusal zekâ oranları arasında bir etkileşimi ortaya çıkarmaya amaçlamıştır. Araştırmada Bar-On Duygusal zekâ ölçeğinden yararlanılmıştır. Duygusal Araştırmada 240 yöneticiye anket uygulanmıştır. Eğitim sektöründe görev yapan yöneticilerin eğitim seviyesi ve alanı, yaş, cinsiyet, denetim alanı, kurumda kıdem süresi gibi değişkenler ile anlamlı bir ilişki bulunamamıştır. Duygusal zekâ liderlik tutumları için gereken beceri ve yeteneği içerisinde barındırmaktadır. Araştırma sonucunda bireye yönelik liderlik tutumu duygusal zekâ ile etkileşimi söz konusu olduğu görülmüştür (İşliel, 2013:82-142).

Başka bir çalışmada Danacı (2015) ise, spor kulüplerini yönetiminden sorumlu olan yöneticilerin duygusal zekâ oranını, liderlik ve duygusal zekâ oranının çalışan bireylere etkisini incelemiştir. Anket yöntemi kullanılmıştır. Çalışmada Wong ve Law’un duygusal zekâ ölçeğinden yararlanılmıştır. Spor kulübünde çalışan 205 yöneticiden anket toplanmıştır. Araştırma sonucunda yöneticiler kendini tanımak için çaba harcadıkları ve duygularını hareketlerine yansıttıklarını ve liderlik ile anlamlı bir ilişki olduğu gözlemlenmiştir (Danac1, 2015:100-156). Eroğlu'nun (2016) araştırmasında ise, yöneticilik, liderlik ve duygusal zekâ kavramlarının birbirleri arasındaki ilişkiyi incelemiştir. Çalışmada duygusal zekâ ve liderlik konusu ile ilgili çeşitli kaynaklarda literatür taraması yapılmıştır. Çalışmanın literatür taraması sonucunda liderin duygusal zekâ düzeyi, liderin etkinliği ile pozitif bir etkileşim söz konusu olduğu belirtilmiştir (Eroğlu, 2016:99).

Taşkıran ve Köse (2016) banka sektöründe görev yapan yönetici pozisyonunda olan bireylerin liderlik stilleri ile duygusal zekâ arasındaki ilişkiyi ortaya koymayı amaçlamıştır. Çalışmada Daniel Goleman'ın duygusal zekâ ölçeği baz alınarak geliştirilen ölçekten ve Bass ve Avolio'un MLQ' den yararlanılmıştır. Farklı pozisyonlarda farklı dört şubede görev yapan 392 lidere anket yapılmıştır. Araştırma sonucunda liderlik stilleri ile duygusal zekâ kavramı ile olumlu bir ilişki olduğu tespit edilmiştir. Liderin kendine olan farkındalığını kurum ilişkilerine yansıtması ile liderlik nitelikleri oluşmaya başlamıştır (Taşkıran \& Köse, 2016: 584-594). Güneş (2016) ise çalışmasında, duygusal zekâ kavramı ile dönüşümcü liderlik tarzının tutumları arasındaki ilişki incelemeyi amaçlamıştır. Salovey ve Mayer EQ ölçeğine göre tasarlanan Wong ve Law ölçeğinin baz alan bir envanter kullanılmıştır. Farklı sektörlerde üst ve orta kademede görev yapan 398 yöneticiye anket uygulanmıştır. Araştırma sonucunda kendi duygularını tanımlayabilmenin, diğer bireylerin duygularını tanımlayabilmenin, duyguların olumlu katkılarından yararlanmanın, duyguları yaşamında uygulayabilmenin duygusal zekâ boyutunu oluşturmakta olduğu tespit edilmiştir. Dönüşümcü liderlik boyutları ile duygusal zekâ arasında anlamlı bir etkileşimin olduğu vurgulanmıştır (Güneş, 2016:131156). Benzer şekilde, Özdemir (2016) duygusal zekâ ile liderlik üzerine yaptığı çalışmada, savunma sanayisi sektöründe faaliyetlerini yürüten kurumda çalışan beyaz yakalıların, duygusal zekâ düzeylerini 
ve liderlik tutumunu arasındaki ilişkiyi incelemeyi amaçlamıştır. Wong ve Law tarafından geliştirilen duygusal zekâ ölçeğinden yararlanılmıştır. Liderlik için Kouzes ve Posner'ın liderlik uygulamaları ölçeğinden yararlanılmıştır. Araştırmada 187 kişinin anketleri değerlendirilmiştir. Anket sonuçlarında ise duygusal zekâ kabiliyeti, liderliğin etkililiğini ve başarısını olumlu yönde etkilediği tespit edilmiştir (Özdemir, 2016:45-81).

Şimşek (2019) ise, duygusal zekâ ve liderlik temelli çalışmasında duygusal zekâ ile liderlik tarzları ve kuramı ile ilgili etkileşimi belirlemeyi amaçlamıştır. Veri toplamak için sivil havacılıkta görev yapan 142 yöneticiye anket yapılmıștır. Araștırma sonuçlarında yöneticilerin duygusal zekâ ile benimsedikleri liderlik stilleri ile aralarında olumlu bir etkileşim olduğu gözlemlenmektedir. Yöneticilerin liderlik tarzları ile duygularını başarılı bir şekilde düzen verebilmesi, duygusal durumu olumlu değerlendirmesi ile olumlu bir etkileşim söz konusu olduğu belirtilmiştir (Şimşek, 2019:28-63). Şit (2019) çalışmasında ise, duygusal zekâ ve liderlik arasındaki etkileşimi ortaya koymayı amaçlamıştır. Şit' in yürüttüğü bu çalışmada çeşitli kaynaklardan literatür taraması yapılmıştır. Çalışmasında, duygusal zekâ kavramı ile liderlik arasında pozitif bir etkileşim olduğunu belirtmiştir. Lider, duygusal zekâ ile duygularını anlayabilir, duygularına olumlu katkı sağlayacak kadar yön verebilmektedir. Bununla birlikte, empati ile bireylerin davranışlarına anlam yükleyebilir, başarılı bir iletişim ile bireyleri güdüleyip olumlu katkı sağlayacak bir şekilde hareketlere yön verebilmektedir. Duygusal zekâ ile lider çalışma ortamının daha uyumlu tutumlar sergilemelerini sağlayarak yaratıcı ve yeni bir şeyler üretebilmek için bir ortam oluşturmakta olduğunu söylemek mümkündür (Şit, 2019:77-79).

Duygusal zekâ ve liderlik konusu üzerine yürütülen çalışmaların sonuçları incelendiğinde duygusal zekâ ve liderlik kavramı üzerinde pozitif bir ilişkinin olduğu tespit edilmiştir. Duygusal zekâ düzeyinin yüksek olması liderlik süreninin de başarı düzeyini artırmaktadır. Duygusal zekâ düzeyi yüksek olan liderlerin işletme içerisinde uyumlu davranışları tetikleyerek yeni fikirler için gerekli olan koşulu sağlamaktadır. Liderin öz farkındalık düzeyi artıkça liderlik niteliklerinde doğru orantıda artmaktadır. Duygusal zekâ kavramı liderlik sürecinde liderin etkinlik düzeyini artırmada olumlu bir ilişkisi vardır. Eğitim seviyesi yükseldikçe duygusal zekâ düzeyinde artış olmaktadır. Yapılan araştırmaların sonucunda duygusal zekâ ile cinsiyet, yaş ve kıdem değişkenleri arasında bir anlamlı ilişki gözlemlenmemiştir. Liderin niteliklerinde duygusal zekâ olmadıkça liderlik yapamayacağını söylemek mümkündür.

Küreselleşmenin ve değişimin çok hızlı olduğu bu döneme liderliğin başarısını ve etkililiğini geliştiren faktör duygusal zekâdır. Bu neden ile duygusal zekâ liderde kilit noktayı oluşturmaktadır. Gelinen noktada yeni teknolojiler ile birlikte işletmeler dönüşüm sürecinde, vasıflı personel olarak çalışan kişilerin bu bandın dışına itilmesi ile iş tatmini noktasında sorun yaşamaları mümkündür. Bu dönüşüm sonucunda meslek veya çalışma alanının bireyler açısından anlamı olan bir faaliyet olma özelliğini kaybetmesi de söz konusudur. Bu da bireylerin "işe yarama" olarak tabir edilebilecek olan duygusal durumlarında bozulmalara neden olabilecek bir durumdur ki bireylerin psikolojik anlamda sorunlar yaşamasının da temelini oluşturabilecek bir husustur (Zafer \& Vardarlier, 2020). Bu zor süreçlerde insanın kendini motive edebilmesi, daima başarma isteğine ve heyecanına sahip olması her zaman mümkün olmamaktadır. Bu nedenle günümüzde büyük ișletmeler, liderlik için olası yıldız adayların tanımlanması, geliştirilmesi ve atamalarında yardımcı olması için tecrübeli liderleri işe almaktadır. Yüksek duygusal zekâya sahip liderler, dinamik duyguların onlara yardım edeceğini ve çalışanlarını motive edebileceğinden emindirler. Aynı zamanda kurumsal duyguları ön planda tutmak, kuruluşun gelişmesi için yaşamsal önem taşımaktadır. Böylelikle işletmeler bünyesindeki yüksek duygusal zekâya sahip liderleri sayesinde negatif durumlarla daha kolay baş edebilmektedir.

\section{SONUÇ}

Duygusal zekâ ve liderlik arasındaki etkileşimi ortaya koymaya çalışan bu çalışmada, duygusal zekâ ve liderlik kavramı irdelenmiş yüksek duygusal zekâya sahip liderlerin özellikleri incelenmiştir. Duygusal zekâ ve liderlik üzerine yürütülen çeşitli çalışmalar üzerinde yapılan literatür taraması incelendiğinde, duygusal zekâ ve liderlik arasında pozitif bir ilişkinin olduğu görülmektedir. Duygusal zekâ, liderlik sürecine etki sağlayacak olumlu nitelikler kazandırmaktadır. Duygusal zekâya sahip lider, kendine olan farkındalığını arttırarak kendine daha iyi yön vererek, sosyal anlamda farkındalığını geliştirerek, kurduğu ilişkileri daha başarılı yönetebilmektedir. 
Son zamanlarda iş dünyasında faaliyet gösteren kurumların birbirlerinden ayrılmasını sağlayacak, rekabetin çetin olduğu çalışma hayatında, teknolojik, sosyal, politik ve ekonomik değişimlerin hızlı bir şekilde değişime uğradığı bu dönemde başarıya ulaştıracak önemli nitelikler arasında duygusal zekâ yer almaktadır. $\mathrm{Bu}$ nedenle kurum yönetiminde, yönetim süreçlerinde, çalışanlarda ve liderlik sürecinde duygusal zekâya sahip kişilerin olması kurumun temel ihtiyaçlar listesinde yer almaktadır. Günümüzün kurum hayatında duyguları gereksiz ya da güçsüzlügün bir simgesi olarak görülüp iş hayatında yeri yok görüşü ile yönetim sağlanabilir. Duygusuz bir çalışma hayatı, kurum da fikir olușturma süreç döngüsünü tıkayıp sürecin ișlevliğini kaybetmesine neden olmaktadır. Bu durumun aksine kurumda duygu, yönetimin bir süreci olarak görülür ise, kurum içerisinde bilgi akışı sağlanır, bilgiler saklanmaz veya gizlenmez, saydamlık sağlanır, çalışan bireyler daha kolay bir şekilde bilgiye erişebilir. Böylelikle değişikliğe ve yeniliğe karşı direnç göstermek yerine gelişime daha açık bir yapıya sahip olurlar.

Duygusal zekâ düzeyinin yüksek olması, bireyin yüzleşmekten korktuğu duyguları ile yüzleşmesine firsat vermektedir. Kendisini değerlendirebilme cesareti verir. Korktuğu ve kaçtığı duygular ile yüzleşmesine firsat sağlamaktadır. Duygusal zekâ duyguların sağladığı nimetleri israf etmeden yararlanmasını sağlar. Duygusal zekâ ile bireyler çeşitli ortamlarda veya koşullarda duygusal okur yazarlık yeteneğine sahip olmaktadır. Duygusal zekâya sahip bireyler sadece kendi duygularını değil, diğer bireylerin hissettiği duygularını da sezebilir, duygularını anlayabilir, kendisini diğer bireylerin yerine koyarak duygu durumlarını yaşayabilir, duygusal ihtiyaçlarını fark edebilmektedir. Bu sayede hem özel hayattaki ilişkilerde hem de çalışma hayatındaki ilişkilerde yapıcı ve sağlıklı sürdürebilir bir ilişki sağlanabilir. Bireylerin ruhsal durumunun hangi davranışları ve tutumları tetiklediğinin bilincinde olur.

Liderlikte duygusal anlamda zeki olmak, kurumun liderlerden ve kurum üyelerinden gerçekleştirmesini beklediği unsurlar hakkında bilgi sahibi olmasıdır. Lider kurumun var oluş nedenini, gelecek için oluşturduğu resmin, önem verdiği değerleri hakkında farkındalık düzeyi arttırmaktadır. Bu bilgileri 1şığında kurum için daha doğru ve etkili amaçlar ve hedefler saptamaktadır. Duygusal zekâsı yüksek olan liderler, kurum içerisinde çalışan veya ekibinde çalışan bireylerin duygularını farkına varabilir, bireylerin duygularını anlayabilir, duygusal anlamda eksik hissettiği yönlerini ve duygusal ihtiyaçlarını farkına varabilir. Bu farkındalık kurumun veya ekibinin ortak amaç, hedef için harekete geçmeyi daha cazip hale getirir ve gerçekleştirilmesi için gerekli olan süreç yer alması ikna edebilme kabiliyetini güçlendirir. Duygusal anlamda zeki olan lider kurumda çalışan bireyleri ortak bir amaç etrafında toplayabilmektedir. Bireylerin içindeki ekip ruhunu oluşturabilir. Liderin oluşturduğu ekip ruhu ortak amaç ve hedef yolunda ilerlerken bu ekip ruhu bireyleri bir arada tutar. Duygusal zekâsı yüksek olan lider, kendi duygularına etkili bir şekilde yön verebilmektedir. Anlık verdiği duygusal tepkileri kontrol altına alabilmektedir. Çalışma ortamında bireylerin duygularını da denetim altında tutabilmektedir. Duygusal denetim ile görüşleri farklı olanların daha çok yapıcı, olumlu, pozitif ve 1lımlı bir ruh halinde olmasını sağlayarak yaratıcı ve yeni fikirlerin oluşması için daha etkili bir çalışma ortamı oluşturmaktadır. Farklı ruh haline sahip olan bireylerin duygu durumlarının yeni ve farklı fikirler üretebilmesine nasıl katkı sağlayacağına farkına varırlar. Böylelikle duygularını kullanmayı öğrenirler. Duygularını değerlendirmeyi bilirler. Duygusal zekâsı yüksek olan lider, yeniliği ve değiş̧imi desteklemek yeni fikirlerin ortaya çıkması için bir ortam oluşturur. Duygusal anlamda zeki lider, tarafların duygusal çıkarlarını anlayarak kolay ve etkili ortak bir yol bulabilmektedir.

Duygusal zekâya sahip bir lider, kurum içerisinde duygusal zekânın varlığını ve etkisini sürdürülmesine katkı sağlar. Kurum içerisinde duygusal zekâ kavramını destekler, kurum üyelerini bu yönde geliştirmeye çalışır. Duygusal zekâyı geliştirmesi için teşvik eder. Kurumda çalışan bireylere model olur. Duygusal zekâ ile neler başarabildikleri hakkında bilgi sağlar ve olumsuz görüşlerini değiştirebilir. Liderlik sürecinde ekip üyeleri ve kurumda çalışan bireylerin liderden beklediği nitelikler de vardır. Kurum veya ekip üyeleri liderden, güven verici ve güvenin hâkim olduğu bir atmosfer oluşturmasını ister. Doğrucu olmasını ister. Söyledikleri ve davranışları arasında bir tutarlılık olmasını bekler. Kendilerini motive etmelerini ister. Başarılı ve etkili bir performans sergilemeleri için liderden yön vermelerini beklerler. Duygusal parlamalarını yön verebilmesini, kendilerini dinleyebilmesini, onun görüş acısı ile bakmasını, duygularını anlamasını ister. Lider bu beklentileri ve nitelikler sergileyebilmesi için duygusal zekâya gereksinim duymaktadır. Liderler duygusal zekâ sayesinde bireyleri etkileyerek sadece konuşarak değil bireyleri canı gönülden dinleyerek ve duygusal durumlarını anlayarak bireyler ile sağlıklı sürdürebilir bir ilişki kurarlar. Böylelikle gücünü 
konumundan değil ilişkilerinden ve etkilemeden almaktadır. Kurumun da bireyleri yönetebilmek için üst hiyerarşisinde yer almak zorunda değildir. Bireylerin akılını iyi okuyarak bireylerin motivasyonunu yükseltecek etkenleri iyi bilir. Liderlerin bu tutumları sergileyebilmesi ve bu niteliklere sahip olabilmesi için duygusal zekânın rolünün büyük olduğunu söylemek mümkündür.

\section{KAYNAKLAR}

Abuamer, F (2016). Hemşirelerde Duygusal Zekâ Ve Liderlik Davranışları Algısı: Bir Kamu Hastanesinde Uygulama, Türkiye Cumhuriyeti Ankara Üniversitesi Sağlık Bilimleri Enstitüsü. Yüksek lisans tezi.

Acar, F. (2002). Duygusal zekâ ve liderlik. Erciyes Üniversitesi Sosyal Bilimler Enstitüsü Dergisi, 12(53-68).

Acar, F. T. (2001). Duygusal Zekâ Yeteneklerinin Göreve Yönelik Ve İnsana Yönelik Liderlik Davranışları ile İlişkisi: Banka şube müdürleri üzerine bir alan araştırması. Yayınlanmamış Doktora Tezi.

Altıntaş, Ö. C. (2009). Duygusal Zekâ Elemanlarının Liderlik Tarzları ve Örgütsel Sonuçlar Üzerindeki Etkisi: Isparta İli İlköğretim Okullarında Bir Uygulama. Gebze Yüksek Teknoloji Enstitüsü, Yayınlanmamış Doktora Tezi, Gebze.

Arıcıoğlu, M. A. (2002). Yönetsel başarının değerlemesinde duygusal zekânın kullanımı: Öğrenci yurdu yöneticileri bağlamında bir araştırma. Akdeniz II BF Dergisi, 4, 26-42.

Aslan, Ş. (2013). Geçmişten Günümüze Liderlik Kuramları Sağlık Yönetimi Bakış Açısıyla. Eğitim Yayınevi.

Aysel, L. (2006). Liderlik Ve Duygusal Zekâ (Master's thesis, Kocaeli Universitesi, Sosyal Bilimler Enstitusu).

Babaoğlan, E. (2010). Okul Yöneticilerinde Duygusal Zekâ.Journal of Kirsehir Education Faculty, 11(1).

Bakan, İ., \& Büyükbeşe, T. (2010). Liderlik "Türleri” Ve “Güç Kaynakları” Na İlişkin MevcutGelecek Durum Karşılaştırması. Karamanoğlu Mehmetbey Üniversitesi Sosyal ve Ekonomik Araştırmalar Dergisi, 2010(2), 73-84.

Bar-On, R. (2006). The Bar-On Model Of Emotional-Social İntelligence (ESI). Psicothema, 18, 13-25.

Bar-On, R., Jam-on, R., \& Bar-Shavit, R. (1997). The Emotional Quotient İnventory (EQ-i): Technical manual.

Bektaş, Ç. (2016). Liderlik Yaklaşımları Ve Modern Liderden Beklentiler. Selçuk Üniversitesi Akşehir Meslek Yüksekokulu Sosyal Bilimler Dergisi, 2(7), 43-53.

Brackett, M. A., \& Salovey, P. (2006). Measuring emotional intelligence with the mayer-saloverycaruso emotional intelligence test (MSCEIT). Psicothema, 18, 34-41.

Cengiz, E., Acuner, T., \& Baki, B. (2006). Liderlerin Sahip Oldukları Duygusal Zekânın Örgütsel Yaratıcılık Üzerine Etkileri: Bir Model Önerisi. Atatürk Üniversitesi Sosyal Bilimler Enstitüsü Dergisi, 7(1), 421-433. 
Cooper, R. K., \& Sawaf, A. (1998). Executive EQ: Emotional Intelligence In Leadership And Organizations. Penguin.

Çakar, U., \& Arbak, Y. (2004). Modern Yaklaşımlar Işı̆̆ında Değişen Duygu-Zekâ İlişkisi Ve Duygusal Zekâ.

Çay, Y. T. (2009). Liderlik Ve Duygusal Zekâ: Uygulamalı Bir Çalışma. Yayınlanmamış Yüksek Lisans Tezi, Hacettepe Üniversitesi Sosyal Bilimler Enstitüsü Siyaset Bilimi ve Kamu Yönetimi Anabilim Dalı.

Danac1, E. (2015). Spor Yöneticilerinin Liderlik ve Duygusal Zekâ Düzeyleri Arasındaki İlişkinin Belirlenmesi: İstanbul İli Örneklemi(Master's thesis, İstanbul Gelişim Üniversitesi Sosyal Bilimler Enstitüsü).

De Weerdt, M., \& Rossi, G. (2012). The Bar-On Emotional Quotient Inventory (EQ-İ): Evaluation Of Psychometric Aspects İn The Dutch Speaking Part Of Belgium. Psychology: Selected papers, 145-172.

Delice, M., \& Günbeyi, M. (2013). Duygusal Zekâ Ve Liderlik İlişkisinin İncelenmesi: Polis Teşkilat1 Örneği. Ataturk University Journal of Economics \& Administrative Sciences, 27(1).

Doğan, S., \& Şahin, F. (2007). Duygusal Zekâ: Tarihsel Gelişimi Ve Örgütler İçin Önemine Kavramsal Bir Bakış. Çukurova Üniversitesi Sosyal Bilimler Enstitüsü Dergisi, 16(1), 231-252.

Edizler, G. (2010). Karizmatik Liderlikte Duygusal Zekâ Boyutuyla Cinsiyet Faktörüne İlişkin Literatürsel Bir Çalışma. Selçuk Illetişim, 6(2), 137-150.

Erdal, M. (2007). İşletmelerde Dönüştürücü Liderlik Davranışlarının Analizi (Yüksek Lisans Projesi). Kahramanmaraş: Sütçü Imam Üniversitesi Sosyal Bilimler Enstitüsü.

Erkuş, A., \& Günlü, E. (2008). Duygusal Zekânın Dönüşümcü Liderlik Üzerine Etkileri. Dokuz Eylül Üniversitesi İsletme Fakültesi Dergisi, 9(2), 187-209.

Eroğlu, E. (2016). Yöneticilikte ve Liderlik Duygusal Zekâ. T.C Beykent Üniversitesi Yönetim Anabilim Dalı, İzmir, Yüksek Lisans Tezi.

Eröz, S. S. (2013). Örgütlerde Duygusal Zekâ. Ballkesir Üniversitesi Sosyal Bilimler Enstitüsü Dergisi, 16(29), 213-242.

Geçikli, F. (2012). Liderlik ve Duygusal Zekâ: Mustafa Kemal ATATÜRK Örneği. Atatürk Illetişim Dergisi, (3), 19-38

George, J. M. (2000). Emotions and leadership: The role of emotional intelligence. Human relations, 53(8), 1027-1055.

Goleman, D. (2011). Duygusal Zekâ Neden IQ’dan Daha Önemli. Çev. Banu Seçkin Yüksel). İstanbul: Varlık/Bilim.

Goleman, D., Boyatzis, R. and McKee, A. (2002). Yeni Liderler. (Çev. Filiz Nayır-Osman Deniztekin). İstanbul: Varlık Yayınları.

Güneş, E. (2016). Duygusal Zekâ ve Liderlik Üzerine Bir Araştırma, T.C Dokuz eylül Üniversitesi Sosyal Bilimler Enstitüsü İşletme Anabilim Dalı Yönetim ve Organizasyon Programı, Yayımlanmış Yüksek Lisans Tezi.

İşliel, K. (2013). Duygusal zekâ ve Liderlik. T.C. Dokuz Eylül Üniversitesi Eğitim Bilimleri Enstitüsü Eğitim Bilimleri Anabilim Dalı, Yayımlanmış Yüksek Lisans Tezi 
Johnson, P. R., \& Indvik, J. (1999). Organizational benefits of having emotionally intelligent managers and employees. Journal of workplace learning.

Kelsay, F. E. (2010). Dönüşümsel liderlik ile duygusal zekâ arasındaki ilişki: kar amacı gütmeyen bir hizmet örgütünde çalışma. Ankara: Hacettepe üniversitesi sosyal bilimler enstitüsü işletme anabilim dalı yönetim organizasyon ve örgütsel davranış bilim dalı.

Kunnanatt, J. T. (2004). Emotional intelligence: The new science of interpersonal effectiveness. Human Resource Development Quarterly, 15(4), 489.

Law, K. S., Wong, C. S., Huang, G. H., \& Li, X. (2008). The effects of emotional intelligence on job performance and life satisfaction for the research and development scientists in China. Asia Pacific Journal of Management, 25(1), 51-69.

Maboçoğlu, F. (2006). Duygusal zekâ ve duygusal zekânın gelişimine katkıda bulunan etkenler. Yayınlanmamış Yüksek Lisans Tezi. Ankara Üniversitesi. Sosyal Bilimler Enstitüsü. Felsefe ve Din Bilimleri Anabilim Dall. Ankara.

Martinez-Pons, M. (1997). The relation of emotional intelligence with selected areas of personal functioning. Imagination, Cognition and personality, 17(1), 3-13.

Mayer, J. D. (2002). MSCEIT: Mayer-Salovey-Caruso emotional intelligence test. Toronto, Canada: Multi-Health Systems.

Mayer, J. D., \& Salovey, P. (2007). Mayer-Salovery-Caruso emotional intelligence test. Toronto: Multi-Health Systems Incorporated.

Mayer, J. D., Salovey, P., \& Caruso, D. R. (2008). Emotional intelligence: New ability or eclectic traits?. American psychologist, 63(6), 503.

Özdemir, K. (2016). Liderlik Uygulamaları ile Duygusal Zekâ Boyutları Arasındaki İlişkinin İncelenmesi., T.C. Süleyman Demirel Üniversitesi Sosyal Bilimler Enstitüsü İşletme Anabilim Dalı, Yayımlanmış Yüksek Lisans Tezi.

Özer, İ. Ç. (2010). Duygusal Zekâ İle Liderlik Tarzları Arasındaki İlişki.

Özsalmanlı, A. Y. (2005). Türkiye'de kamu yönetiminde liderlik ve lider yöneticilik. Manas Üniversitesi Sosyal Bilimler Dergisi, 7(13), 137-146.

Poskey, M. (2006). The İmportance Of Emotional İntelligence İn The Workplace, Why İt Matters More Than Personality. Retrieved April, 17, 2006.

Salovey, P., \& Grewal, D. (2005). The Science Of Emotional İntelligence. Current Directions In Psychological Science, 14(6), 281-285.

Salovey, P., \& Mayer, J. D. (1990). Emotional intelligence. Imagination, cognition and personality, 9(3), 185-211.

Somuncuoğlu, D. (2005). Duygusal Zekâ Yeterliliklerinin Kuramsal Çerçevesi ve Eğitimdeki Rolü. Atatürk Üniversitesi Kazım Karabekir Ĕ̌itim Fakültesi Dergisi, (11), 269-293. 
Sönmez, S. (2010). Örgütlerde Duygusal Zekânın Dönüşümsel Liderlik Üzerindeki Etkisi (Doctoral dissertation, Zonguldak Karaelmas Üniversitesi).

Suciu, S., Petcu, D. A. L. I. A., \& Gherhes, V. A. S. I. L. E. (2010). Emotional intelligence and leadership. Annual Economic Science Series, 16, 549-556.

Şahinkaya, B. (2006). Yöneticilik Ve Liderlikte Duygusal Zekâ (Master's thesis, Balıkesir Üniversitesi Fen Bilimleri Enstitüsü).

Şenocak, M. (2015). Duygusal Zekâ ve Liderlik Tarzlarının Çalışan Verimliliği Üzerine Etkileri (Master's thesis, İstanbul Gelişim Üniversitesi Sosyal Bilimler Enstitüsü).

Şimşek, S. (2019). Yöneticilerin Liderlik Tarzları ile Duygusal Zekâ İlişkisinin İncelenmesi Üzerine Sivil Havacılık Sektöründe Bir Araştırma. Yüksek Lisans Tezi, T.C. Beykent Üniversitesi Sosyal Bilimler Enstitüsü İşletme Yönetim Bilim Dalı, İstanbul.

Şit, U. (2019). Duygusal Zekâ ve Liderlik ilişkisi Üzerine Karşılaştırmalı Literatür Analizi, Beykent Üniversitesi Sosyal Bilimler Enstitüsü İşletme Anabilim Dalı İşletme Yönetim Bilim Dalı, Yüksek Lisans Tezi.

Taşkıran, E., \& Köse, A. (2016). Duygusal Zekânın Liderlik Tarzları Üzerindeki Etkisi: Bankacılık Sektöründe Bir Araştırma. Kafkas Üniversitesi İ̈BF Dergisi.

Tengilimoğlu, D. (2005). Kamu ve Özel Sektör Örgütlerinde Liderlik Davranışı Özelliklerinin Belirlenmesine Yönelik Bir Alan Çalışması. Elektronik Sosyal Bilimler Dergisi, 4(14), 1-16

Thorndike, E. L. (1920). Intelligence And İts Uses. Harper's magazine.

Tuğrul, C. (1999). Duygusal Zekâ. Klinik Psikiyatri, 1, 12-20.

Yıldırım, B. N. (2012). Liderlik Özellikleri Ve Liderlik Tarzlarının Duygusal Zekâ Perspektifinden İncelenmesi. Yayınlanmamış Yüksek Lisans Tezi. Kocaeli Üniversitesi Sosyal Bilimler Enstitüsü, Kocaeli.

Yörük, D., \& Dündar, S. (2011). Türkiye'deki Yerel Yöneticilerin Benimsedikleri Liderlik Tarzlarına Göre Boyun Eğici Davranışlarının İncelenmesi. Atatürk Üniversitesi İktisadi ve İdari Bilimler Dergisi, 25(1), 93-106.

Zafer, C., \& Vardarlier, P. (2020). The Impact of New Technology on Society and Workforce in Production in the Era of Industry 4.0. In Handbook of Research on Strategic Fit and Design in Business Ecosystems (pp. 395-411). IGI Global. 